Check for updates

Cite this: Mater. Adv., 2021, 2,3600

\title{
Carbon-layered double hydroxide nanocomposite for efficient removal of inorganic and organic based water contaminants - unravelling the adsorption mechanism $\uparrow$
}

\author{
Sukanya Kundu ${ }^{\mathrm{ab}}$ and Milan Kanti Naskar (DD *ab
}

\begin{abstract}
Carbon-layered double hydroxide (C-LDH) nanocomposites were synthesized by a simple homogeneous co-precipitation process using as-prepared porous carbon and $\mathrm{Al}, \mathrm{Mg}$ and $\mathrm{Ca}$ precursor salts of the LDH. The synthesized adsorbent was used for the removal of inorganic (fluoride, arsenic, and iron) and organic (cationic dye methylene blue, MB, and anionic dye methyl orange, MO) based water contaminants separately and simultaneously from water. Microstructural analysis revealed the formation of nano-flakelike LDH particles (dia. $=10-15 \mathrm{~nm}$ and length $=50-100 \mathrm{~nm}$ ) adhered onto the surface of carbon nanospheres (50-150 nm). The surface area of the products was in the range of 758-477 $\mathrm{m}^{2} \mathrm{~g}^{-1}$. It rendered maximum adsorption capacities of 22.37, 20.40, 80, 122.1 and $328.95 \mathrm{mg} \mathrm{g}^{-1}$ for $\mathrm{As}(\mathrm{V}), \mathrm{F}^{-}, \mathrm{Fe}(॥) / \mathrm{Fe}\left(\mathrm{III}_{\mathrm{I}}, \mathrm{MB}\right.$ and $M O$, respectively. It was used for simultaneous removal of multiple contaminants like As(v), $\mathrm{F}^{-}, \mathrm{Fe}(\mathrm{II}) /$ Fe(III), MB and MO from water with \% adsorption up to $99.99 \%$. This study illustrates a synergetic effect of the composition (C:LDH mol ratio) and surface properties (total surface area and mesopore:micropore surface area ratio) of the adsorbent on the relative adsorption of various pollutants.
\end{abstract}

Received 25th January 2021, Accepted 6th April 2021

DOI: $10.1039 / \mathrm{d} 1 \mathrm{ma} 00064 \mathrm{k}$

rsc.li/materials-advances application in waste water treatment. However, adsorption is considered as the most efficient and promising method due to its large adaptability in small scale treatment plants, low cost, simple design, regeneration ability and ease of operation. ${ }^{17}$ Several adsorbents including alumina, activated carbon, clay, zeolites etc. have been widely used for removal of water contaminants. Nanomaterials are found to be effective adsorbents for water decontamination due to their high surface to volume ratio. A wide number of studies have reported the removal of water contaminants using carbon-based nano-adsorbents containing a high surface area and the presence of abundant surface functional groups. For the removal of water contaminants, specifically organic pollutants, carbon-based nano-adsorbents are used because of their high surface area. ${ }^{18}$ However, due to the presence of high microporosity ( $<2 \mathrm{~nm}$ pore size) and absence of any ionic counterparts in carbon, carbon based adsorbents have some limitation for the adsorption of most inorganic water pollutants via electrostatic interactions. In recent time, inorganic layered double hydroxide ( $\mathrm{LDH})$ based materials have gained interest due to their unique physicochemical properties. ${ }^{19}$ Generally, LDHs are represented as $\left[\mathrm{M}^{2+}{ }_{(1-X)} \mathbf{M}^{3+}{ }_{(X)}(\mathrm{OH})_{2}\right]^{x+}\left(\mathrm{A}^{n-}\right)_{X / n}$. $y \mathrm{H}_{2} \mathrm{O}$, where $\mathrm{M}^{2+}, \mathrm{M}^{3+}$ and $\mathrm{A}^{n-}$ represent the divalent $\left(\mathrm{Co}^{2+}\right.$, $\left.\mathrm{Cu}^{2+}, \mathrm{Ca}^{2+}, \mathrm{Mg}^{2+}, \mathrm{Zn}^{2+}, \mathrm{Ni}^{2+}, \mathrm{Mn}^{2+}\right)$ metal cations, trivalent metal cations $\left(\mathrm{Al}^{3+}, \mathrm{Mn}^{3+}, \mathrm{Co}^{3+}, \mathrm{Fe}^{3+}, \mathrm{Cr}^{3+}\right)$ and the intercalating anions, respectively. $\mathrm{LDH}$ based adsorbents showed effective adsorption efficiency towards the removal of anionic contaminants 
or cationic pollutants via ion exchange with $\mathrm{M}^{2+}$ ions in the $\mathrm{LDH}$ due to the presence of a large interlayer space with exchangeable anions and a positively charged layer. ${ }^{20,21}$ However, LDH based materials due to their lower surface area than carbon based adsorbents have some restrictions for the removal of organic water pollutants. It is worth mentioning that the multiple oxygenic functional groups on the surface of carbon could help facilitate the formation of carbon based composites in the presence of other adsorbent materials like LDHs. Therefore, carbon based LDH composites (C-LDH) could be effective for the removal of water contaminants via physical adsorption of metal ions on the carbon surface as well as exchange of metal ions with the interlayer anions of the LDH through the formation of chemical bonding with surface hydroxyl groups or other oxygen groups on the carbon surface. $^{22,23}$ The synergistic effect of both the adsorbents i.e., porous carbon and a layered double hydroxide in the form of a composite could improve their adsorption capacity by removing different inorganic and organic water contaminants simultaneously. Huang et $a .^{24}$ demonstrated the removal of $\mathrm{Pb}(\mathrm{II})$ and humic acid from aqueous solution using layered double hydroxide/hollow carbon microsphere composites. An $\mathrm{Fe}_{3} \mathrm{O}_{4} @ \mathrm{C} @$ layered double hydroxide composite was used as a magnetic adsorbent for the removal of uranium. ${ }^{25}$

With the above motivation, the objective of the present work is to synthesize an effective adsorbent i.e., carbon-layered double hydroxide (C-LDH) nanocomposite for simultaneous removal of inorganic (As(v), $\mathrm{Fe}(\mathrm{II}) / \mathrm{Fe}(\mathrm{III})$ and $\mathrm{F}^{-}$) and organic (methylene blue, $\mathrm{MB}$, and methyl orange, MO, dyes) water contaminants. The efficiency of the nanocomposite materials has been investigated by varying different parameters like time, pollutant concentration, temperature and $\mathrm{pH}$ of the solution. In this study, a synergetic effect of the composition (C:LDH mol ratio) and the surface properties (BET surface area and mesoporous: microporous surface area ratio) of the composite has been illustrated for the adsorption of different water contaminants. A mechanistic understanding of the adsorption process for simultaneous removal of different water pollutants has been highlighted. The present work is significant in developing a unique adsorbent material for the removal of all possible water contaminants originating from industrial effluents as well as contaminated natural ground water to be used for domestic purposes.

\section{Materials and methods}

\section{Materials}

Aluminium nitrate nonahydrate $\left(\mathrm{Al}\left(\mathrm{NO}_{3}\right)_{3} \cdot 9 \mathrm{H}_{2} \mathrm{O}\right.$, assay $\left.>99 \%\right)$, calcium nitrate tetrahydrate $\left(\mathrm{Ca}\left(\mathrm{NO}_{3}\right)_{2} \cdot 4 \mathrm{H}_{2} \mathrm{O}\right.$, assay $\left.99.0-102.0 \%\right)$, magnesium nitrate hexahydrate $\left(\mathrm{Mg}\left(\mathrm{NO}_{3}\right)_{2} \cdot 6 \mathrm{H}_{2} \mathrm{O}\right.$, assay $\left.\geq 98.5 \%\right)$, ammonium hydroxide $\left(\mathrm{NH}_{4} \mathrm{OH}, 25 \%\right)$, methylene blue, methyl orange, sodium fluoride ( $\mathrm{NaF}$, assay $\geq 97 \%$ ), ferrous sulphate $\left(\mathrm{FeSO}_{4} \cdot 7 \mathrm{H}_{2} \mathrm{O}\right.$, assay 99.5-102.0\%) and arsenic (1000 $\mathrm{mg} \mathrm{\textrm {L } ^ { - 1 }}$ ) standard solution were purchased from Merck, India, while sodium arsenate heptahydrate $\left(\mathrm{Na}_{2} \mathrm{HAsO}_{4} \cdot 7 \mathrm{H}_{2} \mathrm{O}, 98-102.0 \%\right)$ was obtained from Loba Chemie. Millipore water was used throughout the experiment.

\section{Synthesis procedure}

The carbon-layered double hydroxide (C-LDH) composite was synthesized by a simple homogeneous precipitation process. A solution of $\mathrm{Al}\left(\mathrm{NO}_{3}\right)_{2}, \mathrm{Mg}\left(\mathrm{NO}_{3}\right)_{2}$ and $\mathrm{Ca}\left(\mathrm{NO}_{3}\right)_{2}$ was prepared with $70 \mathrm{~mL}$ Millipore water maintaining their molar ratio of $1: 1.33: 0.66$, respectively (Solution A). As-prepared porous carbon $(\mathrm{ESI} \dagger)^{26}$ was added into solution A under stirring for $24 \mathrm{~h}$ maintaining different molar concentrations (0.015 to $0.06 \mathrm{~mol}$ ) with respect to one unit of $\mathrm{LDH}$ (as prepared in solution A). $2 \mathrm{~mL} \mathrm{NH}_{4} \mathrm{OH}(25 \mathrm{wt} \%$ ) in $20 \mathrm{~mL}$ water was added dropwise into it followed by warming at $60{ }^{\circ} \mathrm{C}$ for $4 \mathrm{~h}$ under stirring (Solution B). After that, the products (C-LDH nanocomposite) were collected via washing with water and drying at $100{ }^{\circ} \mathrm{C}$. Thus, four different samples were prepared designated as $\mathrm{C}_{4 x}-\mathrm{LDH}, \mathrm{C}_{2 x}-\mathrm{LDH}, \mathrm{C}_{3 x / 2}-\mathrm{LDH}$ and $\mathrm{C}_{x}-\mathrm{LDH}$ with carbon contents of $0.06,0.03,0.02$ and $0.015 \mathrm{~mol}$, respectively, where $x$ is the amount of carbon (in mol) with respect to $1 \mathrm{Al}^{3+}: 1.33 \mathrm{Mg}^{2+}: 0.66 \mathrm{Ca}^{2+}$ (mol ratio) of the LDH.

\section{Characterization}

The synthesized products were characterized by XRD (PhilipsX'Pert Pro PW 3050/60, using Ni-filtered $\mathrm{Cu}-\mathrm{K}_{\alpha}$ radiation, $\lambda=0.15418 \mathrm{~nm}$ ), FTIR (Spectrum Two, PerkinElmer), $\mathrm{N}_{2}$ adsorption-desorption, XPS (ULVAC-PHI), FESEM (model: Zeiss, Supra ${ }^{\mathrm{TM}}$ 35VP, Oberkochen, Germany) and TEM (Tecnai G2 30ST (FEI)). In the study of $\mathrm{N}_{2}$ adsorption-desorption, the BET (Brumauer-Emmett-Teller) method was used to measure the specific surface area of the samples, while the BJH (Barrett-Joyner-Halenda) method was adopted to evaluate the pore size distributions of the C-LDH samples. The aluminum, magnesium and carbon contents of the sample were analysed using an inductively coupled plasma atomic emission spectrometer (ICP-AES), ARCOS $130 \mathrm{MV}$, Spectro Analytical Instruments $\mathrm{GmbH}$, Kleve, Germany, and the carbon content was analysed using a C-600 Carbon Analyser, Leco, USA.

To record UV-visible spectra, a UV-vis spectrophotometer (Jasco $\mathrm{V}-730$ ) was used within the wavelength range of 195 to $1100 \mathrm{~nm}$.

\section{Adsorption experiment}

The experiments for the adsorption of arsenate, fluoride, iron, methyl orange and methylene blue on the C-LDH composites were carried out by changing different experimental parameters like the time, adsorbate and adsorbent concentration, $\mathrm{pH}$ and temperature (the pollutant concentration, adsorbent dose, time, $\mathrm{pH}$ and temperature for each experiment are given in the respective section of the Results and discussion part). After the specified time interval, the adsorbents were separated from the aqueous solution by filtration. The absorbance values were measured at the absorption maxima of the respective pollutants. The concentration of pollutant in the filtrate was measured using a UV-vis spectrophotometer. The adsorption capacity $\left(q_{t}\right.$ in $\left.\mathrm{mg} \mathrm{g}^{-1}\right)$ and \% removal of pollutants were estimated by the following equations.

$$
q_{t}=\left(C_{\mathrm{o}}-C_{t}\right) \cdot V / m
$$

$\%$ of pollutants adsorbed $=\left(C_{\mathrm{o}}-C_{\mathrm{e}}\right) / 100 C_{\mathrm{o}}$ 
where the concentrations of the pollutant $\left(\mathrm{mg} \mathrm{L}^{-1}\right)$ at the initial time, at time $t$ and at the equilibrium time are defined by $C_{\mathrm{o}}, C_{t}$ and $C_{\mathrm{e}}$, respectively. $V$ and $m$ are the volume $(\mathrm{mL})$ of the solution and mass of the adsorbent (gm), respectively.

\section{Results and discussion}

\section{Characterization of the synthesized C-LDH composite}

The XRD pattern of the synthesized C-LDH composites is shown in Fig. 1a. The characteristic peaks of layered double hydroxides $(\mathrm{LDH})$ with $2 \theta$ values of $11.5,23.4,34.9,39.6$, 60.9 and 61.1 corresponding to $h k l$ planes of (003), (006), (101), (012), (015), (110) and (113), respectively, are identified. ${ }^{27}$ Fig. S1, $\mathrm{ESI}, \dagger$ presents the plot of normalized intensity $v s .2 \theta$ (degrees). By changing different molar compositions of $\mathrm{C}: \mathrm{LDH}$, there is no significant changes in the XRD peak position of the composites. However, the characteristic peak intensity of the LDH increases with an increase in the content of the LDH in the composites. FTIR spectra of the C-LDH composites are shown in Fig. 1b. The absorption bands at 446 and $654 \mathrm{~cm}^{-1}$ correspond to the $\mathrm{Al}-\mathrm{O}$ and $\mathrm{Mg}-\mathrm{O}$ lattice vibrations, whereas the peak position at $1379 \mathrm{~cm}^{-1}$ is due to the presence of nitrate/carbonate anions in the composites. ${ }^{27}$ The wide absorption band at $3446 \mathrm{~cm}^{-1}$ and the sharp band at $1629 \mathrm{~cm}^{-1}$ are the characteristic stretching and bending vibrations of $\mathrm{O}-\mathrm{H}$ bonds, respectively.

Fig. 2 shows $\mathrm{N}_{2}$ adsorption-desorption isotherms of the four different C-LDH composites; the insets reveal the BJH pore size distribution (desorption) of the respective samples. The isotherms reveal pseudo-type I and pseudo-type IV isotherms, indicating the presence of microporosity and mesoporosity in the samples, respectively. It signifies that both micropores and mesopores are
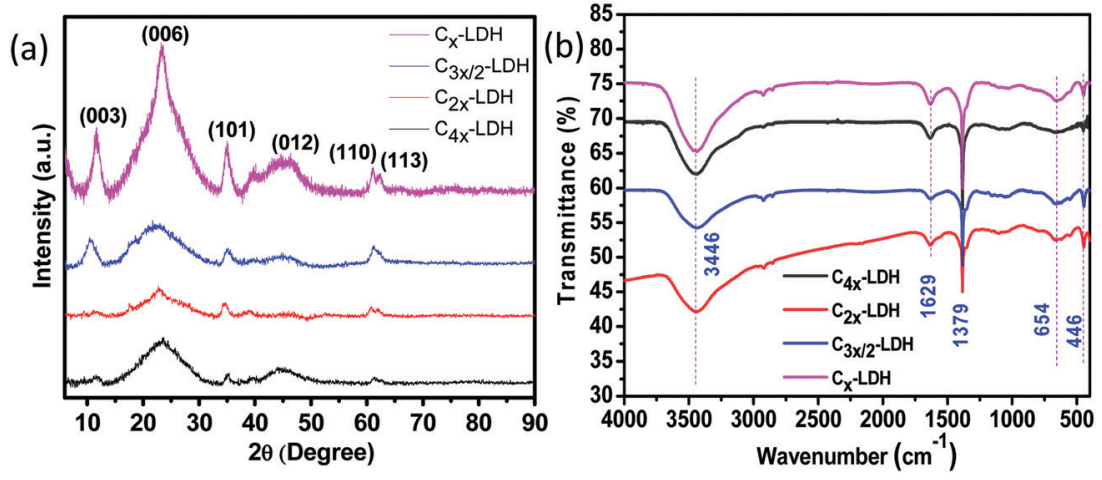

Fig. 1 (a) XRD pattern and (b) FTIR spectra of the C-LDH composites: $C_{4 x}-L D H, C_{2 x}-L D H, C_{3 x / 2}-L D H$ and $C_{x}-L D H$.
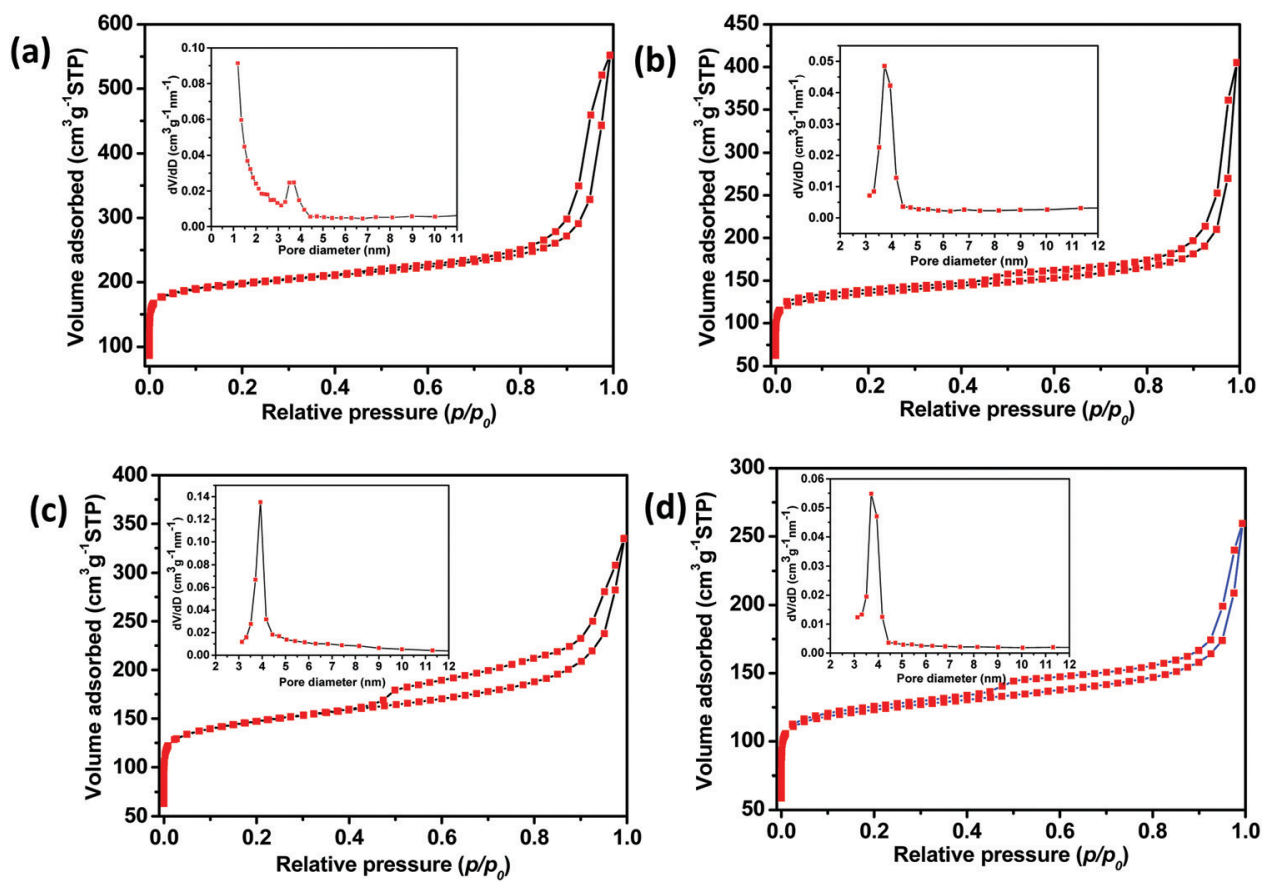

Fig. $2 \mathrm{~N}_{2}$ adsorption-desorption isotherms of C-LDH: (a) $C_{4 x}-\mathrm{LDH}$, (b) $C_{2 x}-\mathrm{LDH}$, (c) $C_{3 x / 2}-L D H$ and (d) $C_{x}-L D H$; the insets present the BJH pore size distributions (desorption) of the corresponding samples. 
Table 1 Textural properties of the C-LDH composite

$$
\underline{\text { Surface area }\left(\mathrm{m}^{2} \mathrm{~g}^{-1}\right)}
$$

\begin{tabular}{|c|c|c|c|c|c|c|}
\hline Sample ID & $S_{\mathrm{BET}}$ & $S_{\text {micropore }}$ & $S_{\text {mesopore }}$ & $\begin{array}{l}S_{\text {mesopore }} \\
S_{\text {micropore }}\end{array}$ & $\begin{array}{l}V_{\mathrm{p}} \\
\left(\mathrm{cm}^{3} \mathrm{~g}^{-1}\right)\end{array}$ & $\begin{array}{l}\text { Pore diamete } \\
\text { (nm) }\end{array}$ \\
\hline $\mathrm{C}_{4 x}-\mathrm{LDH}$ & 758 & 611 & 147 & 0.240 & 0.857 & $1.2 / 3.6$ \\
\hline $\mathrm{C}_{2 x}-\mathrm{LDH}$ & 520 & 424 & 96 & 0.226 & 0.628 & 3.7 \\
\hline $\mathrm{C}_{3 x / 2}-\mathrm{LDH}$ & 558 & 430 & 128 & 0.297 & 0.519 & 3.9 \\
\hline $\mathrm{C}_{x}-\mathrm{LDH}$ & 477 & 397 & 80 & 0.201 & 0.402 & 3.7 \\
\hline
\end{tabular}

Note: $S_{\mathrm{BET}}=\mathrm{BET}$ surface area, $S_{\text {micropore }}=$ micropore surface area, $S_{\text {mesopore }}=$ mesopore surface area and $V_{\mathrm{p}}=$ total pore volume .

present in each sample. Notably, for all the samples $\mathrm{C}_{4 x}-\mathrm{LDH}$, $\mathrm{C}_{2 x}-\mathrm{LDH}, \mathrm{C}_{3 x / 2}-\mathrm{LDH}$ and $\mathrm{C}_{x}-\mathrm{LDH}$, there occurs a steep rise of the isotherms at lower relative pressure $\left(p / p_{\mathrm{o}}<0.01\right)$ and at higher relative pressure $\left(p / p_{\mathrm{o}}<0.8\right)$; the former is due to the presence of microporosity while the latter demonstrates interparticle mesoporosity in the samples. Table 1 gives the BET surface area, pore volume and pore diameter of the samples. The porous carbon sample used for the preparation of the C-LDH composite has a BET surface area and pore volume of $752 \mathrm{~m}^{2} \mathrm{~g}^{-1}$ and $1.155 \mathrm{cc} \mathrm{g}^{-1}$, respectively. ${ }^{26}$ During formation of the C-LDH composite, the molecular species of the $\mathrm{LDH}$ precursors could block partly $^{28}$ the interparticle mesopores of carbon particles, thereby decreasing the BET mesopore surface area and pore volume of the composite (Table 1). The pore diameter of the samples is in the range of 3.6-3.9 $\mathrm{nm}$ while sample $\mathrm{C}_{4 x}$ - $\mathrm{LDH}$ shows a bimodal pore size distribution at around $1.2 \mathrm{~nm}$ and $3.6 \mathrm{~nm}$ (inset of Fig. 2a). It is to be noted that except for sample $\mathrm{C}_{3 x / 2}-\mathrm{LDH}$ there is a decreasing trend of the total BET surface area, micropore surface area and mesopore surface area in the order of
$\mathrm{C}_{4 x}-\mathrm{LDH}>\mathrm{C}_{2 x}-\mathrm{LDH}>\mathrm{C}_{x}-\mathrm{LDH}$. However, the pore volumes for all the samples decrease in the order of $\mathrm{C}_{4 x}-\mathrm{LDH}>\mathrm{C}_{2 x}-\mathrm{LDH}>$ $\mathrm{C}_{3 x / 2}-\mathrm{LDH}>\mathrm{C}_{x}-\mathrm{LDH}$. It is worth mentioning that, with the decrease of the carbon content in the composite, the total BET surface area, micropore surface area, mesopore surface area and pore volume decreased. The anomalous result of sample $\mathrm{C}_{3 x / 2}-\mathrm{LDH}$ in terms of total surface area, and mesopore and micropore surface area could be due to the shape of the pore geometry. Interestingly, Fig. 2c shows that the hysteresis loop of sample $\mathrm{C}_{3 x / 2}-\mathrm{LDH}$ is more expanded compared to the other samples. It is worth mentioning that all the samples depict H3 type hysteresis loops, indicating slit like mesopores. For sample $\mathrm{C}_{3 x / 2}-\mathrm{LDH}$, the more expanded hysteresis loop of the isotherm indicates a higher degree of capillary condensation of $\mathrm{N}_{2}$ in the mesopores compared to that of sample $\mathrm{C}_{2 x} \mathrm{LDH}$, rendering the maximum ratio of the mesopore to micropore surface area ( $\left.S_{\text {mesopore }} / S_{\text {micropore }}\right)$ value. As the micropore surface area values of $\mathrm{C}_{2 x}$ - $\mathrm{LDH}$ and $\mathrm{C}_{3 x / 2}$-LDH are comparable, the higher mesopore surface area of $\mathrm{C}_{3 x / 2}$-LDH contributed a higher BET surface area than that of sample $\mathrm{C}_{2 x}-\mathrm{LDH}$. It is worth noting that an optimum concentration of carbon with respect to the $\mathrm{LDH}$ showed maximum $S_{\text {mesopore }} / S_{\text {micropore, }}$ rendering maximum removal efficiency.

An XPS study was performed to investigate the surface elemental states of the C-LDH composites. Fig. 3a shows the presence of $\mathrm{Al}, \mathrm{Mg}, \mathrm{Ca}, \mathrm{O}$ and $\mathrm{C}$ in all four samples. Fig. 3b-e reveal that the binding energies of $\mathrm{Al} 2 \mathrm{p}, \mathrm{Mg} 2 \mathrm{p}, \mathrm{Ca} 2 \mathrm{p}$ and $\mathrm{C} 1 \mathrm{~s}$ are found to be $75.07,50.94,352.85$ and $284.49 \mathrm{eV}$, respectively. Interestingly, the binding energies of the above elemental states shifted slightly from their standard values. It could be due to compositional variations and the change in the chemical
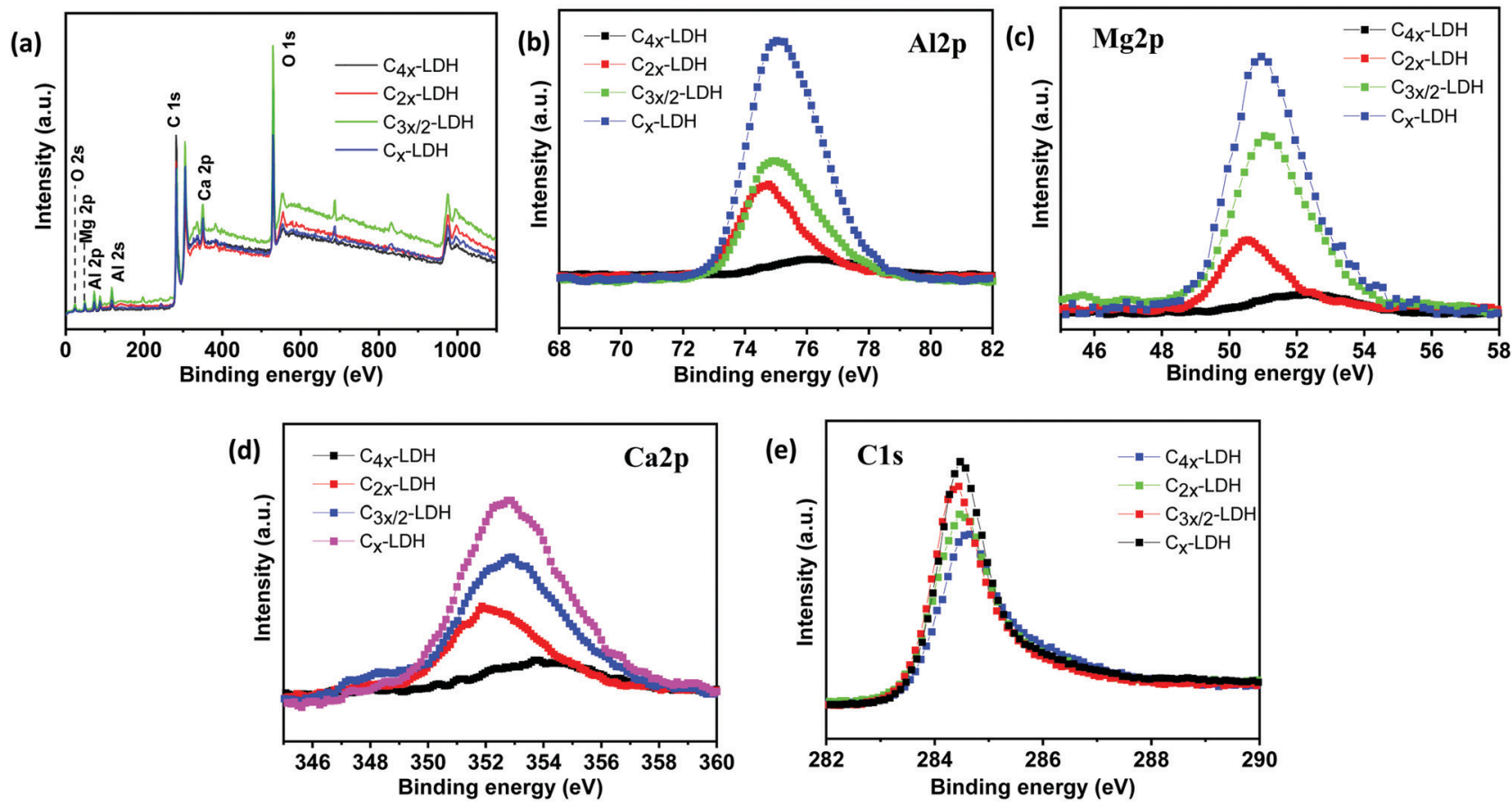

Fig. 3 XPS spectra of C-LDH: (a) full spectrum and (b) Al2p, (c) Mg2p (d) Ca2p and (e) C1s. 
environment. In this case the sharing of elements with neighboring atoms is different in the composite samples. The binding energy of the deconvoluted peak of $\mathrm{Al} 2 \mathrm{p}$ for the four different samples shows that aluminum is present in the form of $\mathrm{Al}(\mathrm{OH})_{3}(\mathrm{BE}: 74.8 \pm 0.1 \mathrm{eV})$ and $\mathrm{AlOOH}(\mathrm{BE}: 75.2 \pm 1.2 \mathrm{eV})$. $\mathrm{AlOOH}$ is formed due to addition of excess ammonium hydroxide $\left(\mathrm{NH}_{4} \mathrm{OH}\right)$ during the synthesis process. Interestingly, the $\mathrm{C}_{4 x}$-LDH sample contains mostly $\mathrm{AlOOH}$ instead of $\mathrm{Al}(\mathrm{OH})_{3}$. On the other hand, the binding energy of Mg2p and Ca2p for the four different $\mathrm{C}-\mathrm{LDH}$ shows that magnesium and calcium are present in the form of $\mathrm{Mg}^{2+}\left(\mathrm{Mg}(\mathrm{OH})_{2}, \mathrm{BE}: 50.49-51.4 \mathrm{eV}\right)$ and $\mathrm{Ca}^{2+}\left(\mathrm{Ca}(\mathrm{OH})_{2}\right.$, BE: 352.6-354.12 eV). The quantitative estimation from XPS study for all four samples is shown in Table S1, ESI. $\dagger$ It was observed that the atomic\% of carbon increases in the order of $\mathrm{C}_{4 x}-\mathrm{LDH}>\mathrm{C}_{2 x}-\mathrm{LDH}>\mathrm{C}_{3 x / 2}-\mathrm{LDH}>$ $\mathrm{C}_{x}$-LDH. However, a little deviation in the $\mathrm{Al}: \mathrm{Mg}: \mathrm{Ca}$ atomic ratio is noticed for these samples. During the measurement, removal of surface oxides and contaminants by $\mathrm{Ar}^{+}$ion etching could cause a number of side effects altering the composition of the upper surface. ${ }^{29}$ During the study of XPS, monoatomic ion guns $\left(\mathrm{Ar}^{+}\right.$ions) are used to clean the surface of the sample. Sputtering with single ions may cause sample modification and several types of damage like ion implantation or atomic mixing, which leads to altering the composition of the investigated samples. $^{30-32}$ However, the ICP-AES technique was applied to confirm the atomic\% of $\mathrm{Al}, \mathrm{Mg}$ and $\mathrm{Ca}$ while $\mathrm{C} \%$ was analysed by a carbon analyser. Table $\mathrm{S} 2$, ESI, $\dagger$ shows the $\mathrm{C}, \mathrm{Al}, \mathrm{Mg}$ and $\mathrm{Ca}$ contents in the sample. Based on the ICP-AES analysis, it is to be noticed that the $\mathrm{Al}: \mathrm{Mg}$ : Ca ratio in the sample was found to be $1: 1.31-1.38: 0.66-0.79$, which is comparable to the experimentally calculated value of $1: 1.33: 0.66$.

Fig. 4 presents the FESEM images of the samples (a) $\mathrm{C}_{4 x}-\mathrm{LDH}$, (b) $\mathrm{C}_{2 x}-\mathrm{LDH}$, (c) $\mathrm{C}_{3 x / 2}-\mathrm{LDH}$ and (d) $\mathrm{C}_{x}-\mathrm{LDH}$; the highly magnified images of the corresponding samples are shown by arrows. The LDH particles are highly agglomerated and adhered onto the surface of nanospherical/spheroid shape carbon particles. In the FESEM images, the nanoflake shape $\mathrm{LDH}$ is found to be increased with an increase in the concentration of the $\mathrm{LDH}$ compared to the carbon content of the $\mathrm{C}-\mathrm{LDH}$ composites and follows the order of $\mathrm{C}_{4 x}-\mathrm{LDH}<\mathrm{C}_{2 x}-\mathrm{LDH}<\mathrm{C}_{3 x / 2}-\mathrm{LDH}<$ $\mathrm{C}_{x} \mathrm{LDH}$. The FESEM image of the porous carbon sample is shown in Fig. S2, ESI, $\dagger$ to get a more intuitive comparison between the as-prepared porous carbon sample and carbonLDH composites (Fig. 4). TEM images (Fig. 5) reveal that the particle size of carbon is in the range of 50-150 nm where overlapping LDH sheets (diameter $=10-15 \mathrm{~nm}$ and length $=50$ $100 \mathrm{~nm}$ ) are adhered onto the surface of the carbon spheres.

\section{Adsorption study of the C-LDH composite for the removal of} $\operatorname{As}(\mathrm{v}), \mathrm{F}^{-}, \mathrm{Fe}(\mathrm{II}) / \mathrm{Fe}(\mathrm{III}), \mathrm{MB}$ and $\mathrm{MO}$

Effect of the contact time. Fig. 6 depicts the effect of the contact time for adsorption of different pollutants: (a) $\mathrm{As}(\mathrm{v})$, (b) $\mathrm{F}^{-}$, (c) $\mathrm{Fe}(\mathrm{II}) / \mathrm{Fe}$ (III), (d) MB and (e) MO by the C-LDH nanocomposites with their initial concentrations of $1.87,3,10,8$ and $32.7 \mathrm{ppm}$, respectively, an adsorbent dosage of $0.5 \mathrm{~g} \mathrm{~L}^{-1}$ each at $\mathrm{pH} \sim 7$ and temperature $30{ }^{\circ} \mathrm{C}$. It shows that within $5 \mathrm{~min}$ the rate of
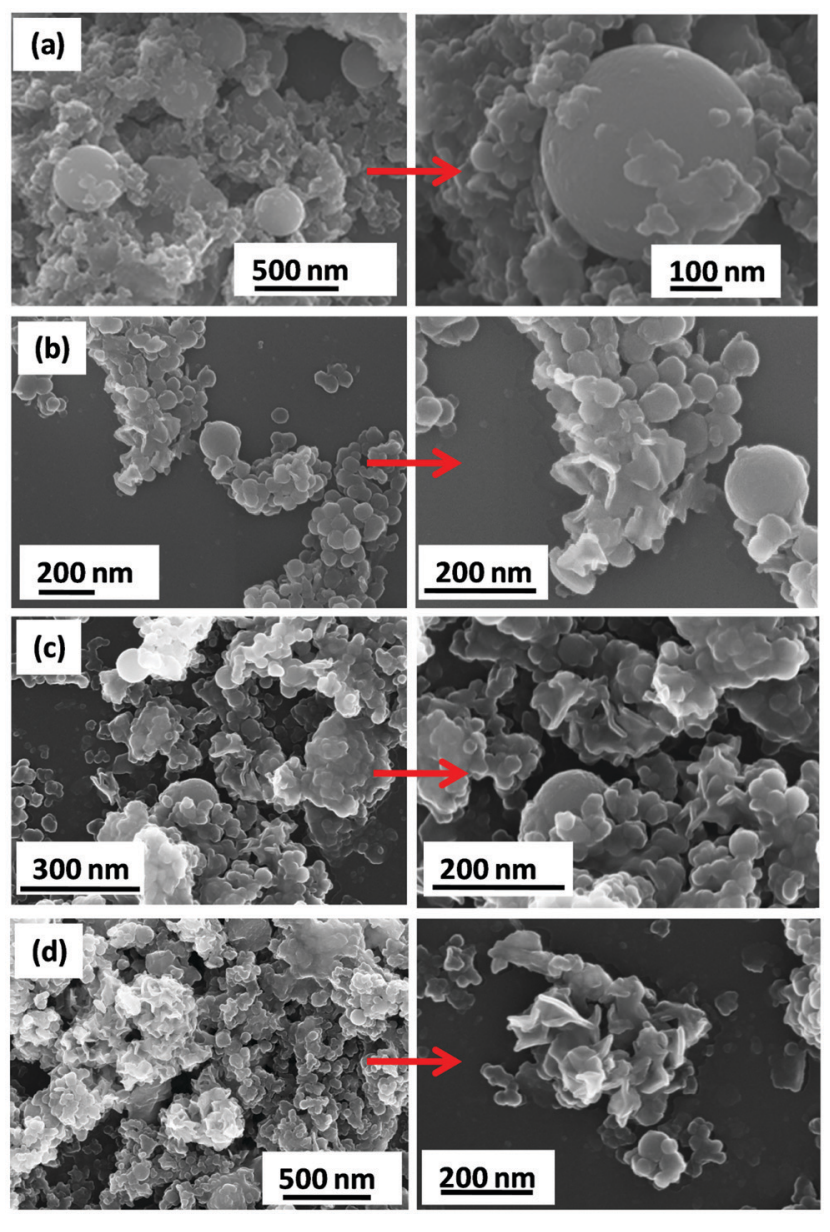

Fig. 4 FESEM images of the C-LDH composites: (a) $C_{4 x}-L D H$, (b) $C_{2 x}-L D H$, (c) $\mathrm{C}_{3 x / 2}-\mathrm{LDH}$ and (d) $\mathrm{C}_{x}-\mathrm{LDH}$.

adsorption is very fast for all the contaminants. It is due to the presence of a large number of vacant adsorption sites at the initial stage of adsorption. The percentage removal of the contaminants like $\mathrm{H}_{2} \mathrm{AsO}_{4}{ }^{-}, \mathrm{F}^{-}$, and $\mathrm{Fe}(\mathrm{II}) / \mathrm{Fe}(\mathrm{III})$ increased steadily up to $60 \mathrm{~min}$ followed by their slow adsorption until the equilibrium is reached at $180 \mathrm{~min}$. For the removal of $\mathrm{MB}$ and MO, the adsorption equilibrium is reached at $60 \mathrm{~min}$. Table S3, ESI, $\dagger$ summarizes the percentage removal of the different contaminants at $5 \mathrm{~min}, 60 \mathrm{~min}$ and $180 \mathrm{~min}$ by the different C-LDH composites. It is worth noting that for the removal of As(v) (Fig. 6a) and $\mathrm{F}^{-}$(Fig. 6b) the removal capacity (\%) of the sample follows the order of $\mathrm{C}_{3 x / 2}-\mathrm{LDH}>\mathrm{C}_{x}-\mathrm{LDH}>$ $\mathrm{C}_{2 x}-\mathrm{LDH}>\mathrm{C}_{4 x}-\mathrm{LDH}$. The maximum removal \% of $\mathrm{As}(\mathrm{v})$ and $\mathrm{F}^{-}$ for sample $\mathrm{C}_{3 x / 2}-\mathrm{LDH}$ could be attributed to the high mesopore : micropore surface area ratio (Section 3.1) and also it contained a significant amount of $\mathrm{LDH}$ compared to the carbon content. However, sample $\mathrm{C}_{x}$-LDH having the maximum amount of $\mathrm{LDH}$ shows a lower removal \% compared to that of $\mathrm{C}_{3 x / 2}-\mathrm{LDH}$, corroborating with the lower mesopore : micropore surface area. On the other hand, for the removal of $\mathrm{Fe}(\mathrm{II}) / \mathrm{Fe}(\mathrm{III}), \mathrm{MB}$ and MO, the trend of the adsorption \% for the samples is in the order of $\mathrm{C}_{4 x}-\mathrm{LDH}>\mathrm{C}_{2 x}-\mathrm{LDH}>\mathrm{C}_{3 x / 2}-\mathrm{LDH}>\mathrm{C}_{x}-\mathrm{LDH}$, which is in tune with the same order of the carbon content and total surface 

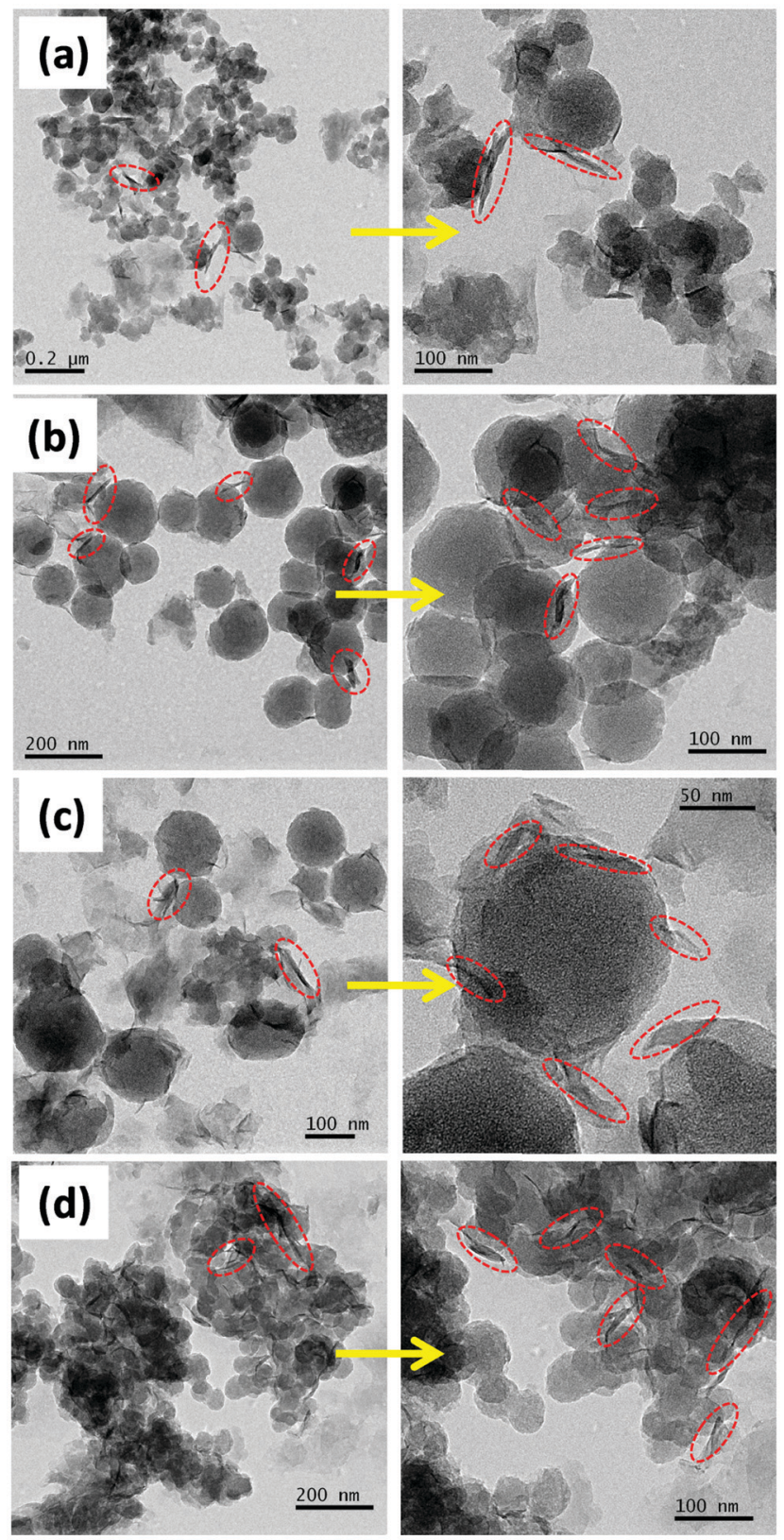

Fig. 5 TEM images of the C-LDH composites: (a) $C_{4 x}-L D H$, (b) $C_{2 x}-L D H$, (c) $\mathrm{C}_{3 \times / 2}-\mathrm{LDH}$ and (d) $\mathrm{C}_{x}-\mathrm{LDH}$.

area. In this case both the carbon content and surface area play a significant role for the adsorption efficiency. Interestingly, for the adsorption of anionic (inorganic) water contaminants such as $\mathrm{As}(\mathrm{v})$ (in the form of $\mathrm{H}_{2} \mathrm{AsO}_{4}{ }^{-}$and $\mathrm{HAsO}_{4}{ }^{2-}$ ) and $\mathrm{F}^{-}$, the $\mathrm{LDH}$ plays a favorable role for their adsorption. However, for the adsorption of cationic inorganic water contaminants like $\mathrm{Fe}(\mathrm{II}) /$ $\mathrm{Fe}(\mathrm{III})$ and organic dyes (MB and MO), a highly porous carbon material is the best choice.

It is inferred that, for the C-LDH based nanocomposite as an adsorbent, the nature of the adsorbents and their relative concentration in the composite, total surface area and mesopore : micropore surface area ratio synergistically affect the removal of different inorganic and organic based water contaminants.
To determine the leading mechanism for adsorption of the different pollutants, the adsorption data were fitted with different kinetic models. Fig. S3-S7 in the ESI $\dagger$ show (a) pseudo-first order and (b) pseudo-second order kinetic models for the adsorption of $\mathrm{As}(\mathrm{V}), \mathrm{F}^{-}, \mathrm{Fe}(\mathrm{II}) / \mathrm{Fe}(\mathrm{III}), \mathrm{MB}$ and $\mathrm{MO}$, respectively. Table S4, ESI, $\uparrow$ summarizes the kinetics data obtained from the respective curves of the kinetic models. By examining the maximum $R^{2}$ values $(\geq 0.99)$ from these data, it is confirmed that pseudo-second order kinetic models were best fitted. The highest adsorption capacity values were obtained from the fitted curve of pseudo-second order kinetics. These results are found to be the same as the experimental data obtained from the plot of percentage removal vs. time (Fig. 6).

Effect of the adsorbate (pollutant) concentration. The effect of the initial concentrations of $\mathrm{As}(\mathrm{v})(2-10 \mathrm{ppm}), \mathrm{F}^{-}$(5-30 ppm), $\mathrm{Fe}(\mathrm{II}) / \mathrm{Fe}(\mathrm{III})(2-20 \mathrm{ppm}), \mathrm{MB}$ (3-25 ppm) and MO (3-163 ppm) on the adsorption capacity of the different C-LDH composites was studied with contact time: $180 \mathrm{~min}$, adsorbent (sample) dosage: $0.5 \mathrm{~g} \mathrm{~L}^{-1}$, temperature: $30^{\circ} \mathrm{C}$ and pH: $6.8 \pm 0.2$. Fig. $7 \mathrm{a}-\mathrm{e}$ show the change of the adsorption capacity $\left(q_{\mathrm{e}}\right)$ with the initial concentrations of the different contaminants (a) $\mathrm{As}(\mathrm{v})$, (b) $\mathrm{F}^{-}$, (c) $\mathrm{Fe}(\mathrm{II}) / \mathrm{Fe}(\mathrm{III}),(\mathrm{d}) \mathrm{MB}$ and (e) MO. With increasing the initial concentrations of all the pollutants, the individual adsorption capacity increased. For removal of As(v) (Fig. 7a) and $\mathrm{F}^{-}$(Fig. 7b), the maximum adsorption capacity of the C-LDH composites follows the order of $\mathrm{C}_{3 x / 2} \mathrm{LDH}>\mathrm{C}_{2 x}-\mathrm{LDH}>\mathrm{C}_{x}-\mathrm{LDH}>\mathrm{C}_{4 x^{-}}$ LDH. This trend could be correlated with the carbon content in the composite, BET surface area $\left(S_{\mathrm{BET}}\right)$ and mesopore/micropore surface area ratio. With a decrease in the carbon content and increase in the LDH concentration in the composite, the adsorption efficiency increased due to the increase in the anion exchange capacity of the LDH. Accordingly, $\mathrm{C}_{4 x}$-LDH showed the lowest adsorption efficiency compared to the other composites. However, the above explanation does not hold good for samples $\mathrm{C}_{3 x / 2}$-LDH and $\mathrm{C}_{x}$-LDH. Instead of having a higher LDH content in sample $\mathrm{C}_{x}-\mathrm{LDH}$ compared to $\mathrm{C}_{3 x / 2}-\mathrm{LDH}$, the former showed a lower adsorption capacity than the latter because of the lower $S_{\mathrm{BET}}$ and mesopore:micropore surface area ratio. It is worth mentioning that $\mathrm{C}_{3 x / 2}-\mathrm{LDH}$ showed the maximum $\mathrm{As}(\mathrm{v})$ and $\mathrm{F}^{-}$ removal capability among all the composites. It is inferred that the combined effects of the LDH content, BET surface area, and mesopore:micropore surface area in the composites play a critical role for the removal of $\mathrm{As}(\mathrm{v})$ and $\mathrm{F}^{-}$from water. In the case of $\mathrm{Fe}(\mathrm{II} / \mathrm{Fe}$ (III) (Fig. 7c), MB (Fig. 7d) and MO (Fig. 7e) removal, the adsorption capacity follows the order of $\mathrm{C}_{4 x}-\mathrm{LDH}>$ $\mathrm{C}_{2 x}-\mathrm{LDH}>\mathrm{C}_{3 x / 2}-\mathrm{LDH}>\mathrm{C}_{x}-\mathrm{LDH}$. Among all the samples, $\mathrm{C}_{4 x}-\mathrm{LDH}$ showed the maximum adsorption capacities due to the maximum carbon content in the composite and highest BET surface area.

In order to investigate the relationship between the adsorbate (pollutant) and adsorbent (C-LDH nanocomposite), the adsorption data is fitted with different isotherm models. Fig. S8-S12 in the ESI $\dagger$ present the plots obtained from the (a) Langmuir and (b) Freundlich isotherm models for the adsorption of As(v) (Fig. S8, ESI $\dagger$ ), $F^{-}$(Fig. S9, ESI $\dagger$ ), Fe(II)/Fe(III) (Fig. S10, ESI $\dagger$ ), MO (Fig. S11, ESI $\dagger$ ) and MB (Fig. S12, ESI $\dagger$ ). The detailed fitting parameters of the Langmuir and Freundlich models for the adsorption of the 
(a)

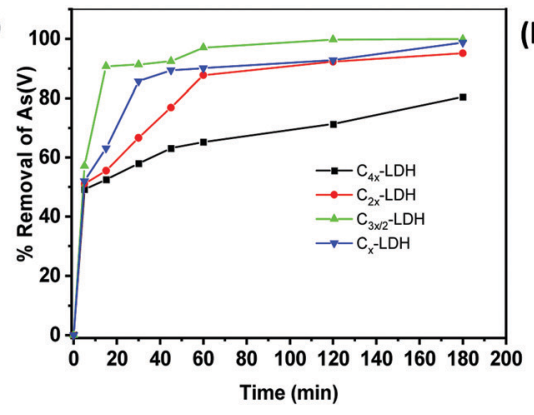

(b)

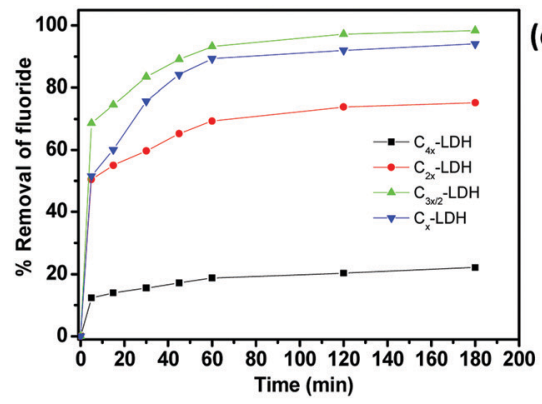

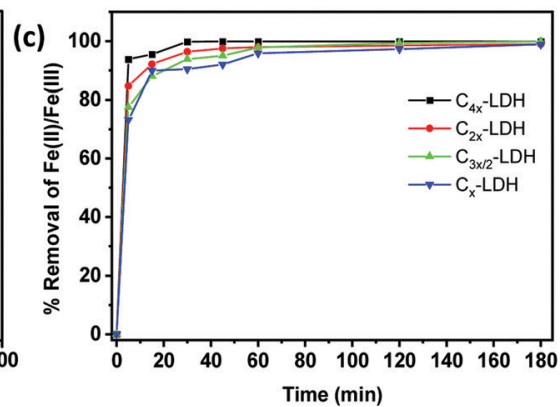
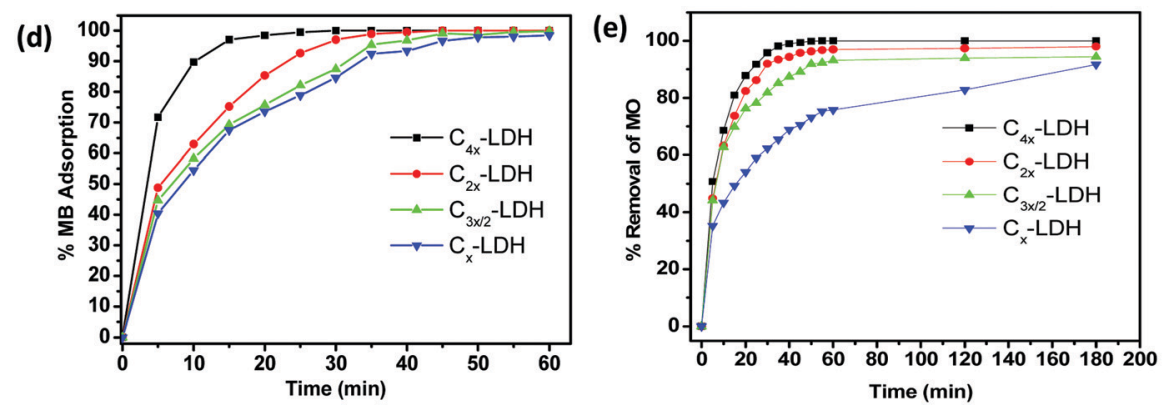

Fig. 6 Percentage (\%) removal vs. time plot of the different $C$ - LDH composites $\left(C_{4 x}-L D H, C_{2 x}-L D H, C_{3 x / 2}-L D H\right.$ and $\left.C_{x}-L D H\right)$ for the adsorption of (a) As(v), (b) $F^{-}$, (c) $\mathrm{Fe}($ II)/Fe(III), (d) $M B$ and (e) MO.

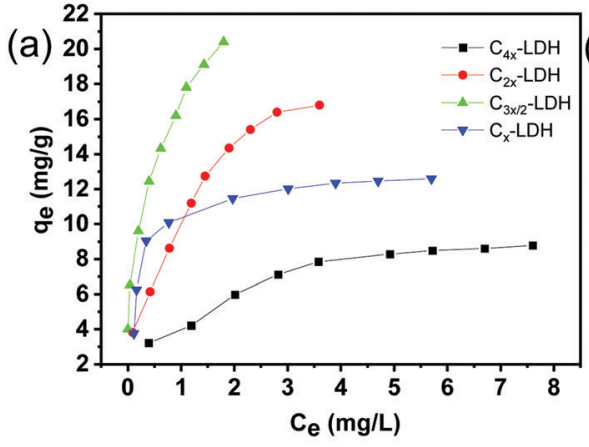

(d)

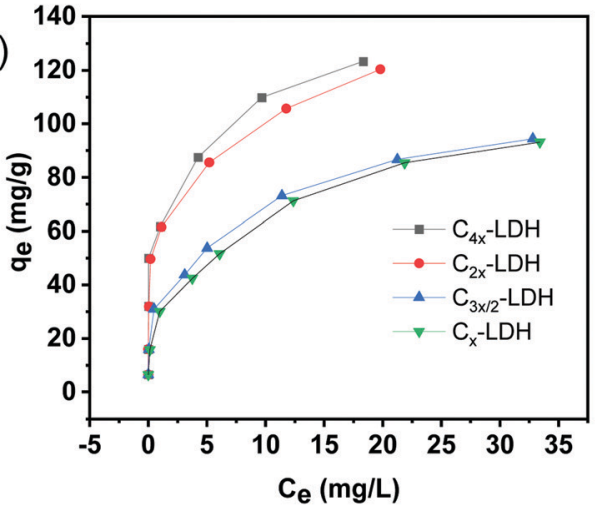

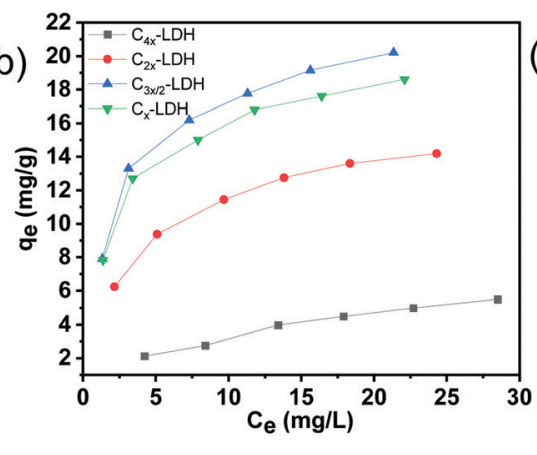
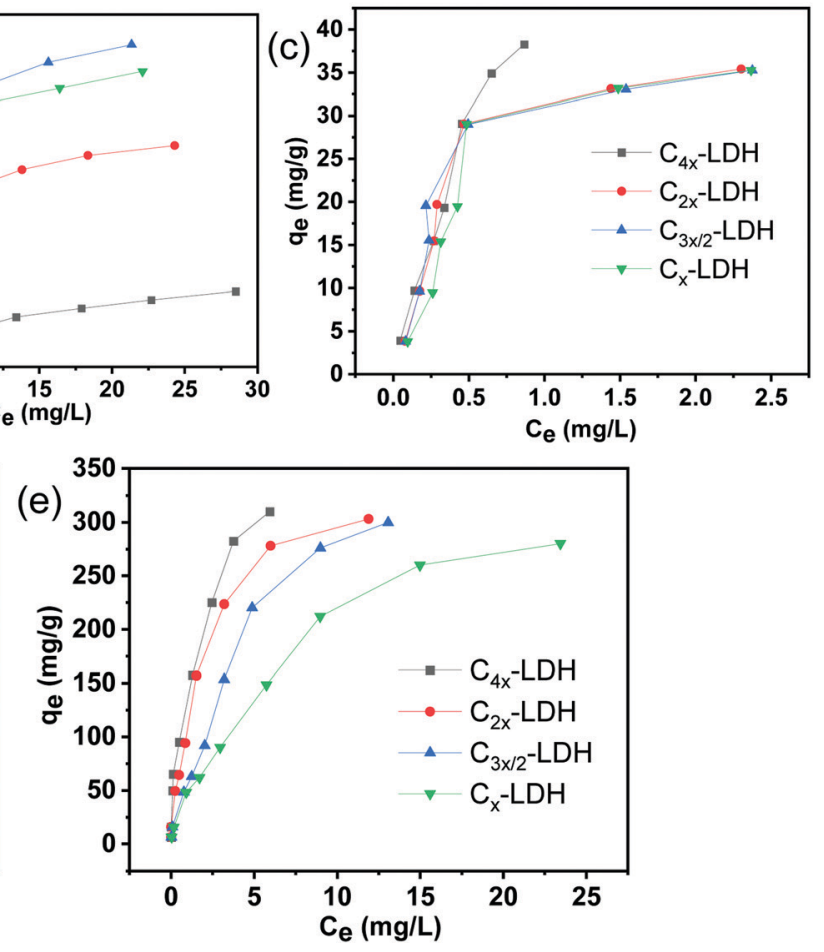

Fig. 7 Plot of the equilibrium adsorption capacity with the equilibrium concentration of the different $\mathrm{C}$-LDH composites $\left(\mathrm{C}_{4 x}-\mathrm{LDH}, \mathrm{C}_{2 x}-\mathrm{LDH}, \mathrm{C}_{3 x / 2}-\mathrm{LDH}\right.$ and $\left.C_{x}-L D H\right)$ for the adsorption of (a) As(v), (b) $F^{-}$, (c) Fe(II)/Fe(III), (d) MB and (e) MO.

pollutants are shown in Table S5, ESI.† The Langmuir isotherm is expressed by the dimensionless constant separation factor $R_{\mathrm{L}}$.

$$
R_{\mathrm{L}}=\frac{1}{1+K_{\mathrm{L}} C_{0}}
$$

where $C_{\mathrm{o}}\left(\mathrm{mg} \mathrm{L}^{-1}\right)$ is the initial concentration of the pollutant and $K_{\mathrm{L}}\left(\mathrm{L} \mathrm{mg}^{-1}\right)$ is the Langmuir constant. The $R_{\mathrm{L}}$ value was found in the range of 0 to 1 , which indicates favorable adsorption at room temperature. The linear forms of the Langmuir and Freundlich isotherms are expressed as follows: 
Langmuir isotherm: $C_{\mathrm{e}} / q_{\mathrm{e}}=C_{\mathrm{e}} / q_{\mathrm{m}}+1 / K_{\mathrm{L}} \cdot q_{\mathrm{m}}$

Freundlich isotherm: $\log q_{\mathrm{e}}=\log K_{\mathrm{F}}+1 / n_{\mathrm{F}} \log C_{\mathrm{e}}$

where $C_{\mathrm{e}}\left(\mathrm{mg} \mathrm{\textrm {L } ^ { - 1 }}\right), q_{\mathrm{m}}\left(\mathrm{mg} \mathrm{g}^{-1}\right)$ and $q_{\mathrm{e}}\left(\mathrm{mg} \mathrm{g}^{-1}\right)$ are the equilibrium adsorbate concentration, maximum adsorption capacity and equilibrium adsorption capacity, respectively, while $n_{\mathrm{F}}$ and $\mathrm{K}_{\mathrm{F}}$ are the adsorption intensity and Freundlich constant, respectively. The $\mathrm{n}$ values obtained from the Freundlich isotherms are found to be greater than 1, signifying high affinity between the adsorbate and adsorbent, indicating a chemisorption process. ${ }^{33}$ The Langmuir isotherm model is fitted better for the adsorption of $\mathrm{As}(\mathrm{v}), \mathrm{F}^{-}, \mathrm{Fe}(\mathrm{II}) / \mathrm{Fe}(\mathrm{III})$ and MB as confirmed by the $R^{2}$ values, while the Freundlich model is fitted well for the adsorption of MO. The maximum adsorption capacity values for $\mathrm{As}(\mathrm{v})$ and $\mathrm{F}^{-}$removal are found to be 22.37 and $20.40 \mathrm{mg} \mathrm{g}^{-1}$, respectively, using $\mathrm{C}_{3 x / 2}-\mathrm{LDH}$, while sample $\mathrm{C}_{4 x}-\mathrm{LDH}$ showed highest removal efficiencies of 80.00, 122.10 and $328.95 \mathrm{mg} \mathrm{g}^{-1}$ for the adsorption of $\mathrm{Fe}(\mathrm{II}) / \mathrm{Fe}(\mathrm{III}), \mathrm{MB}$ and MO, respectively, at room temperature.

Effect of the adsorbent dose. The effect of the sample dose on the adsorption capacity of the different C-LDH composites for the removal of the different water contaminants (initial concentration of $\mathrm{As}(\mathrm{v}): 10.76 \mathrm{ppm}, \mathrm{F}^{-}: 25.2 \mathrm{ppm}, \mathrm{Fe}(\mathrm{II}) / \mathrm{Fe}(\mathrm{III})$ : 18.48 ppm, MB: 25 ppm and MO: 25 ppm) was studied with contact time: $180 \mathrm{~min}$, temperature: $30{ }^{\circ} \mathrm{C}$ and pH: $6.8 \pm 0.2$. Fig. 8a-e show the change of the removal \% of (a) As(v), (b) $\mathrm{F}^{-}$, (c) $\mathrm{Fe}(\mathrm{II}) / \mathrm{Fe}$ (III), (d) MB and (e) MO by changing to the different adsorbent doses. For the adsorption of As(v), the removal efficiency increased sharply up to an adsorbent dose of $0.5 \mathrm{~g} \mathrm{~L}^{-1}$ followed by a slow increase up to an adsorbent dose of $1.2 \mathrm{~g} \mathrm{~L}^{-1}$ (Fig. 8a). Adsorbent dosage $0.5 \mathrm{~g} \mathrm{~L}^{-1}$ is found to be the optimum concentration for higher removal efficiency ( $93 \%$ for $\mathrm{C}_{3 x / 2}-\mathrm{LDH}$ ) and maximum adsorption capacity $\left(20.37 \mathrm{mg} \mathrm{g}^{-1}\right.$ for $\left.\mathrm{C}_{3 x / 2}-\mathrm{LDH}\right)$. A higher dose of adsorbent signifies a higher surface area providing a larger number of active binding sites for the contaminant ions. Consequently, the adsorption efficiency increased with increasing adsorbent amount, and stabilization of adsorption is obtained after a certain concentration of adsorbent, which could be due to overlapping of active sites at higher doses.

For fluoride removal, with an increase in the adsorbent dose from $0.2 \mathrm{~g} \mathrm{~L}^{-1}$ to $1.3 \mathrm{~g} \mathrm{~L}^{-1}$, the rate of removal of fluoride ions is increased. For samples $\mathrm{C}_{4 x}-\mathrm{LDH}, \mathrm{C}_{2 x}-\mathrm{LDH}, \mathrm{C}_{3 x / 2}-\mathrm{LDH}$ and $\mathrm{C}_{x}-\mathrm{LDH}$, the \% removal increases from 10 to $24 \%, 15.5$ to $36.5 \%, 26.5$ to $53 \%$, and 22.6 to $48.3 \%$, respectively, with the increase in the adsorbent dose. It is found that the maximum adsorption capacity value $\left(q_{\mathrm{m}}\right)$ reduced with an increase in the adsorbent concentration. As an example, sample $\mathrm{C}_{3 x / 2}-\mathrm{LDH}$ with dose $0.2 \mathrm{~g} \mathrm{~L}^{-1}$ showed a $q_{\mathrm{m}}$ and \% removal of $25.45 \mathrm{mg} \mathrm{g}^{-1}$ and $20.2 \%$, respectively, while, with an increase in the adsorbent dose to $1.3 \mathrm{~g} \mathrm{~L}^{-1}$, the respective values were found to be $10.27 \mathrm{mg} \mathrm{g}^{-1}$ and $53 \%$. To get a better adsorption capacity and removal efficiency, the optimum adsorbent dose of $0.5 \mathrm{~g} \mathrm{~L}^{-1}$ was used for further study for fluoride removal.

For removal of $\mathrm{Fe}(\mathrm{II}) / \mathrm{Fe}(\mathrm{III})$, the above phenomenon was observed, i.e., with increasing the adsorbent dose, the \% removal of $\mathrm{Fe}(\mathrm{II}) / \mathrm{Fe}(\mathrm{III})$ increases significantly. For sample $\mathrm{C}_{4 x^{-}}$ LDH with an adsorbent dose of $0.5 \mathrm{~g} \mathrm{~L}^{-1}$, the \% removal was found to be $95.6 \%$, while it was $\sim 88 \%$ for the other three samples. The adsorption capacity enhances with an increase in the dose of the adsorbent. To achieve the highest adsorption capacity $\left(q_{\mathrm{m}}\right)$ with good removal efficiency, the optimum adsorbent dose of $0.5 \mathrm{~g} \mathrm{~L}^{-1}$ was used for further study for $\mathrm{Fe}(\mathrm{II}) / \mathrm{Fe}(\mathrm{III})$ removal.
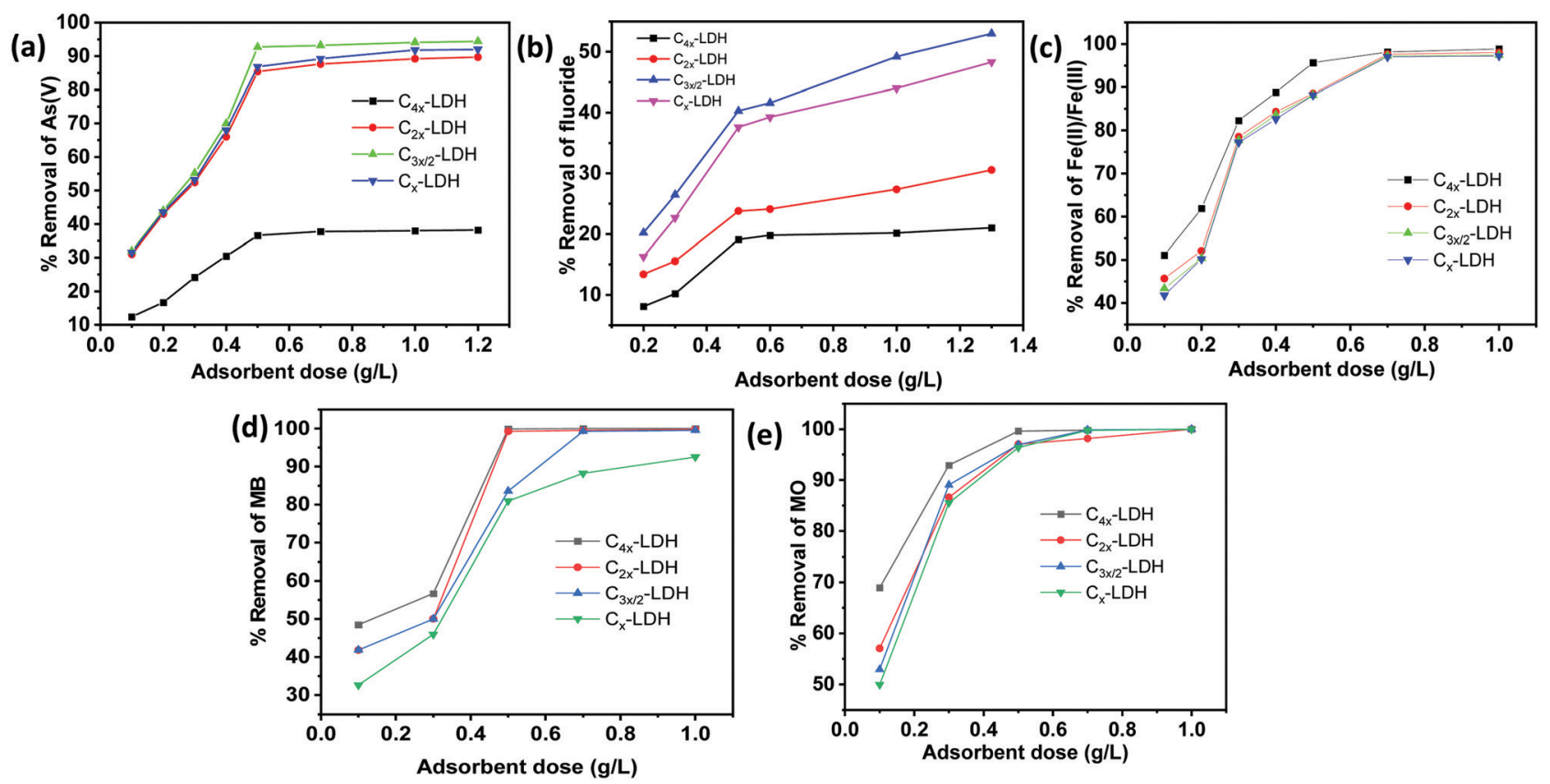

Fig. 8 Effect of the adsorbent dose for adsorption of (a) As(v), (b) $\mathrm{F}^{-}$, (c) Fe(॥)/Fe(॥I), (d) MB and (e) MO on the C-LDH composites. 
Similarly, for adsorption of $\mathrm{MB}$ (cationic dye) and $\mathrm{MO}$ (anionic dye), the adsorption efficiency increased with increasing adsorbent dose up to $1.0 \mathrm{~g} \mathrm{~L}^{-1}$. The optimum removal efficiency with a better adsorption capacity value is obtained for the adsorbent dose of $0.5 \mathrm{~g} \mathrm{~L}^{-1}$. This dose amount of $0.5 \mathrm{~g} \mathrm{~L}^{-1}$ is used for further study for removal of MB and MO.

Effect of $\mathbf{p H}$. The solution $\mathrm{pH}$ has a significant effect for uptake of pollutants as it determines the surface charge of the adsorbent, chemical nature of the adsorbate and degree of ionization. The effect of $\mathrm{pH}$ in the range of 3-9 on the removal of the pollutants (As(v): $10.76 \mathrm{ppm}, \mathrm{F}^{-}: 25.2 \mathrm{ppm}, \mathrm{Fe}(\mathrm{II}) / \mathrm{Fe}(\mathrm{III})$ : 18.48 ppm, MB: 25 ppm and MO: 25 ppm) was studied by using the optimum adsorbent dose $\left(0.5 \mathrm{~g} \mathrm{~L}^{-1}\right)$ of the composites equilibrated for a time of $180 \mathrm{~min}$, temperature $30{ }^{\circ} \mathrm{C}$ and $\mathrm{pH}$ $6.8 \pm 0.2$. To study the $\mathrm{pH}$ effect on the adsorption of the different pollutants, the concentrations of $\mathrm{As}(\mathrm{V}), \mathrm{F}^{-}, \mathrm{Fe}(\mathrm{II}) / \mathrm{Fe}(\mathrm{III})$, MB and MO were taken as 10.76, 25.2, 18.48, 25 and $25 \mathrm{mg} \mathrm{L}^{-1}$, respectively. Fig. 9a-e show the $\mathrm{pH}$ effect for the removal of the different pollutants (a) $\mathrm{As}(\mathrm{v})$, (b) $\mathrm{F}^{-}$, (c) $\mathrm{Fe}(\mathrm{II}) / \mathrm{Fe}(\mathrm{III}),(\mathrm{d}) \mathrm{MB}$ and (e) MO. Before studying the effect of the $\mathrm{pH}$ on the removal efficiency, the point of zero charge for all samples was estimated by the mass titration process developed by Noh and Schwarz. ${ }^{34}$ The values of $\mathrm{pH}_{\text {(PZC) }}$ (point of zero charge) were found to be 7.4, 7.6, 7.78 and 8.01 for sample $\mathrm{C}_{4 x}-\mathrm{LDH}, \mathrm{C}_{2 x}-\mathrm{LDH}, \mathrm{C}_{3 x / 2}-\mathrm{LDH}$ and $\mathrm{C}_{x}-\mathrm{LDH}$, respectively. At lower $\mathrm{pH}$, the surface of the samples is positively charged and showed higher adsorption due to electrostatic interactions between the positively charged $\mathrm{C}-\mathrm{LDH}$ composite and the negatively charged pollutants like $\mathrm{H}_{2} \mathrm{AsO}_{4}{ }^{-}, \mathrm{F}^{-}$, and MO. However, for the removal of $\mathrm{Fe}(\mathrm{II}) / \mathrm{Fe}(\mathrm{III})$ and cationic dye (MB), higher adsorption occurs at $\mathrm{pH} \geq 7$. It is worth mentioning that at $\mathrm{pH} \geq 7$ the surface negative charges on the C-LDH composites increased, which in turn enhanced the adsorption capacity of $\mathrm{Fe}(\mathrm{II}) / \mathrm{Fe}(\mathrm{III})$ and $\mathrm{MB}$ via electrostatic attraction.

The rate of adsorption for removal of As(v) was found to be higher at lower $\mathrm{pH}$ followed by a decreasing trend with an increase in the $\mathrm{pH}$ of the solution (Fig. 9a). The decrease of the adsorption percentage at higher $\mathrm{pH}$ is due to electrostatic repulsion between negatively charged $\mathrm{H}_{2} \mathrm{AsO}_{4}{ }^{-}$in solution and $\mathrm{OH}^{-}$ions. Reversely, at a lower $\mathrm{pH}$ the strong coulombic interaction between negatively charged $\mathrm{H}_{2} \mathrm{AsO}_{4}{ }^{-}$and the positive charged C-LDH surface plays a key role for adsorption of arsenic. With increasing $\mathrm{pH}$ of the solution, the \% adsorption decreased by $25.9,30.8,7.8$ and $32.45 \%$ for sample $\mathrm{C}_{4 x}-\mathrm{LDH}, \mathrm{C}_{2 x}-\mathrm{LDH}$, $\mathrm{C}_{3 x / 2}-\mathrm{LDH}$ and $\mathrm{C}_{x}-\mathrm{LDH}$, respectively.

The sorption efficiency for removal of $\mathrm{F}^{-}$was found to be higher in a lower $\mathrm{pH}$ range than a basic $\mathrm{pH}$ range (Fig. 9b). The reduced adsorption efficiency at basic $\mathrm{pH}$ is due to the electrostatic repulsion between the negatively charged C-LDH surfaces and $\mathrm{F}^{-}$ions. The highest $\mathrm{F}^{-}$removal was observed at around pH 5 for all the C-LDH samples. Because of the high anion exchange capacity and high surface-active binding sites, $\mathrm{C}_{3 x / 2^{-}}$ LDH showed high removal efficiency.

The $\mathrm{pH}$ effect on the adsorption of $\mathrm{Fe}(\mathrm{II}) / \mathrm{Fe}(\mathrm{III})$ is seen to be increased with an increase in the $\mathrm{pH}$ of the solution (Fig. 9c). The maximum adsorption was observed in the $\mathrm{pH}$ range of 4.5 to 7. At $\mathrm{pH}<4.5$, the adsorption capacity is decreased due to competition between $\mathrm{H}^{+}$ions and positive $\mathrm{Fe}(\mathrm{II}) / \mathrm{Fe}(\mathrm{III})$ ions. When the $\mathrm{pH}$ of the surrounding medium increased, the negative charges on the surface of the C-LDH composite increased, leading to greater electrostatic interaction between the adsorbent and $\mathrm{Fe}(\mathrm{II}) / \mathrm{Fe}(\mathrm{III})$ ions. However, a further increase of the $\mathrm{pH}$ in the solution $(\mathrm{pH}>7)$ led to precipitation via formation of hydroxide complexes such as $\mathrm{Fe}(\mathrm{OH})_{2}, \mathrm{Fe}(\mathrm{OH})_{3}$ etc. Therefore, all adsorption
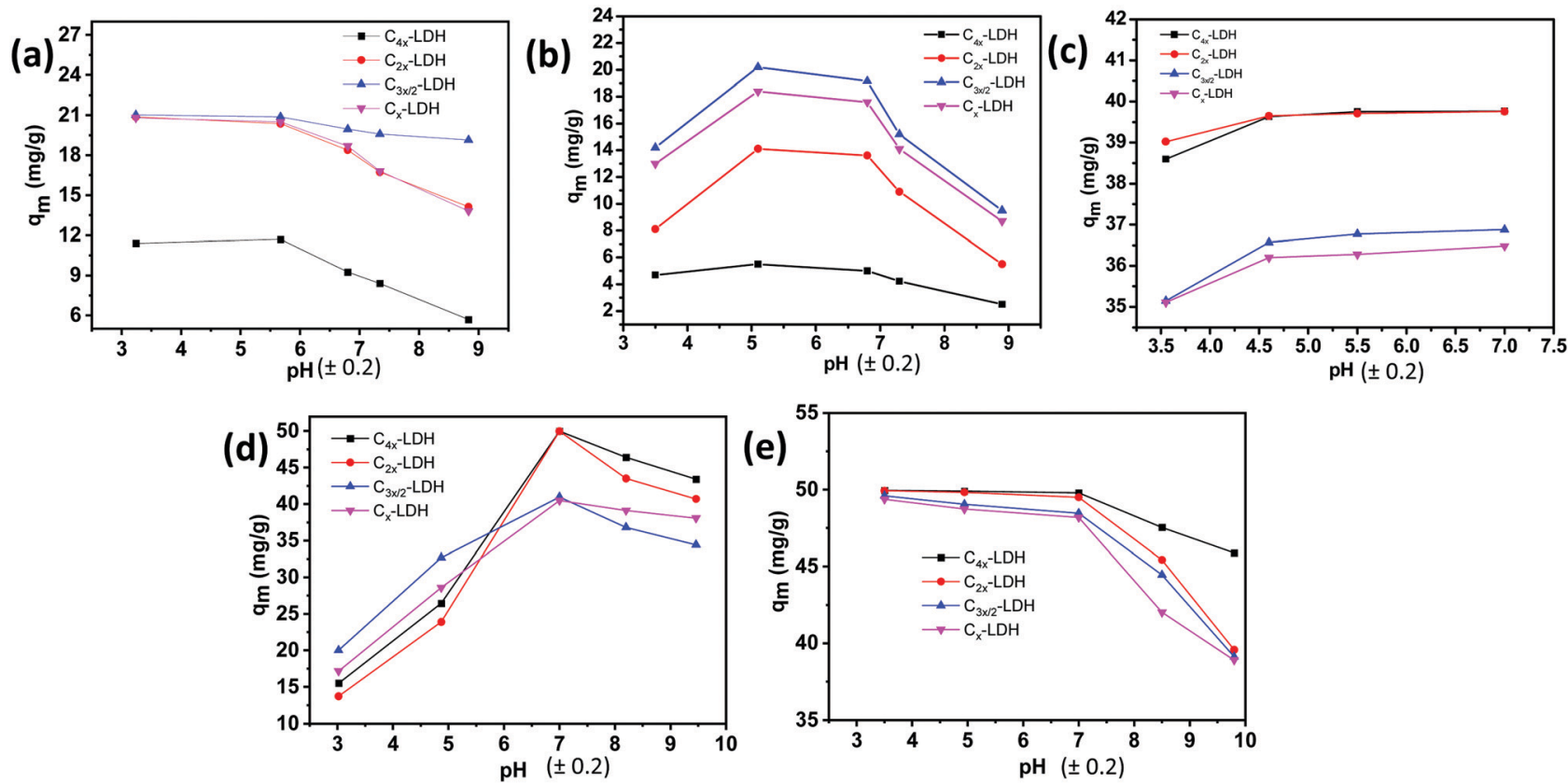

Fig. 9 The effect of $\mathrm{pH}$ on the adsorption capacity of the different $\mathrm{C}-\mathrm{LDH}$ composites $\left(\mathrm{C}_{4 x}-\mathrm{LDH}, \mathrm{C}_{2 x}-\mathrm{LDH}, \mathrm{C}_{3 x / 2}-\mathrm{LDH}\right.$ and $\left.\mathrm{C}_{x}-\mathrm{LDH}\right)$ for the adsorption of (a) As(v), (b) $\mathrm{F}^{-}$, (c) Fe(॥)/Fe(III), (d) MB and (e) MO. 
experiments for removal of iron are conducted at a $\mathrm{pH}$ less than 7 to avoid the effect of precipitation, confirming $\mathrm{Fe}(\mathrm{II}) / \mathrm{Fe}(\mathrm{III})$ ion removal by adsorption only.

To study the effect of the $\mathrm{pH}$ on the adsorption of $\mathrm{MB}$, the electrostatic repulsion between cationic dye $\mathrm{MB}$ and the positively charged C-LDH surface inhibits the rate of adsorption of $\mathrm{MB}$ at lower $\mathrm{pH}$. However, the adsorption efficiency was found to be significantly increased at $\mathrm{pH} 7$ (Fig. 9d). The reason behind this is that the amino group of $\mathrm{MB}$ becomes free from protonation at neutral $\mathrm{pH}$, leading to electrostatic attraction with vacant adsorption sites of the C-LDH composites. ${ }^{35}$ Further, the adsorption of MB decreases at alkaline $\mathrm{pH}$. The negative charge on the C-LDH surface increases at higher $\mathrm{pH}$, causing repulsion between oxyanions of the MB dye (formed through complex formation) and the adsorbent. ${ }^{36}$

The adsorption capacity of methyl orange on the surface of C-LDH was found to be higher at lower pH (Fig. 9e), which is due to electrostatic attraction between the anionic dye MO and positively charged C-LDH composites. With an increase in the $\mathrm{pH}$ of the solution $(>7)$, the adsorption capacity reduces due to electrostatic repulsion between the anionic dye, MO, and the negatively charged surface of the composites.

Effect of temperature. To understand the temperature effect on the sorption capacity of $\mathrm{C}-\mathrm{LDH}$ for $\mathrm{As}(\mathrm{v}), \mathrm{F}^{-}, \mathrm{Fe}(\mathrm{II}) / \mathrm{Fe}(\mathrm{III}), \mathrm{MB}$ and MO removal, different temperatures were selected in the range of $30{ }^{\circ} \mathrm{C}(303 \mathrm{~K})$ to $60{ }^{\circ} \mathrm{C}(333 \mathrm{~K})$ with initial $\mathrm{As}(\mathrm{v}), \mathrm{F}^{-}$, $\mathrm{Fe}(\mathrm{II}) / \mathrm{Fe}(\mathrm{III}), \mathrm{MB}$ and $\mathrm{MO}$ concentrations of 10.76, 25.2, 18.48, 25 and $25 \mathrm{mg} \mathrm{L}^{-1}$, respectively, with contact time: $180 \mathrm{~min}$, and pH: $6.8 \pm 0.2$. Fig. 10 shows the effect on the \% removal efficiency of the C-LDH nanocomposites for removal of different contaminants on the C-LDH composites with temperature. The rate of reaction between the adsorbent and adsorbate during the adsorption process is influenced by the temperature. With an increase in temperature, the diffusion of adsorbate molecules increases through the external laminar layer into the pores of the adsorbent, resulting in a change of the equilibrium adsorption capacity. ${ }^{37}$ For both cases, the adsorption capacity is increased by an increase in temperature up to $40 \pm 2{ }^{\circ} \mathrm{C}(313 \pm 2 \mathrm{~K})$. With a further increase in temperature, the rate of removal remains almost constant for all C-LDH composites. This could be due to disruption of the active binding sites at the adsorbent or destruction of adsorbate molecules or an increasing desorption tendency of contaminant ions from the interface of the solution. ${ }^{38}$ $\mathrm{C}_{3 x / 2}$-LDH showed the maximum removal efficiency as compared to the other $\mathrm{C}-\mathrm{LDH}$ samples. For $\mathrm{C}_{3 x / 2}-\mathrm{LDH}$, the adsorption capacity increases from $22.30 \mathrm{mg} \mathrm{g}^{-1}$ to $23.14 \mathrm{mg} \mathrm{g}^{-1}$ (for As(v)), $19.15 \mathrm{mg} \mathrm{g}^{-1}$ to $19.99 \mathrm{mg} \mathrm{g}^{-1}$ (for $\mathrm{F}^{-}$), 35.25 to $37.36 \mathrm{mg} \mathrm{g}^{-1}$ (for $\mathrm{Fe}(\mathrm{II}) / \mathrm{Fe}(\mathrm{III})$ ), 41.79 to $43.95 \mathrm{mg} \mathrm{g}^{-1}$ (for $\mathrm{MB}$ ) and 48.46 to $48.83 \mathrm{mg} \mathrm{g}^{-1}$ (for MO) with an increase in temperature from $30 \pm 2{ }^{\circ} \mathrm{C}(303 \pm 2 \mathrm{~K})$ to $40 \pm 2{ }^{\circ} \mathrm{C}(313 \pm 2 \mathrm{~K})$.

\section{Simultaneous removal of $\mathrm{As}(\mathrm{v}), \mathrm{F}^{-}, \mathrm{Fe}(\mathrm{II}) / \mathrm{Fe}(\mathrm{III}), \mathrm{MB}$ and $\mathrm{MO}$}

Due to the higher removal efficiency of sample $\mathrm{C}_{3 x / 2}-\mathrm{LDH}$ for the adsorption of water contaminants, particularly $\mathrm{As}(\mathrm{v})$ and $\mathrm{F}^{-}$, it was used for simultaneous removal of $\mathrm{As}(\mathrm{V}), \mathrm{F}^{-}, \mathrm{Fe}(\mathrm{II}) / \mathrm{Fe}(\mathrm{III})$, $\mathrm{MB}$ and MO from water. In this study, the experiments were carried out by changing the concentrations of the adsorbate (Fig. 11a) (keeping sample dose $3.75 \mathrm{~g} \mathrm{~L}^{-1}$ ) and the adsorbent dosage (Fig. 11b) (keeping a pollutant concentration of $5 \mathrm{mg} \mathrm{L}^{-1}$ ) with contact time $180 \mathrm{~min}$, at $\mathrm{pH} 6.8 \pm 0.2$, and temperature $30^{\circ} \mathrm{C}$ for each. The percentage removal of different pollutants simultaneously by using the $\mathrm{C}_{3 x / 2}-\mathrm{LDH}$ composite was compared with the as-prepared carbon sample and LDH sample (Fig. S13 in the ESI $\dagger$ ). It is worth noting that a similar experimental procedure was used
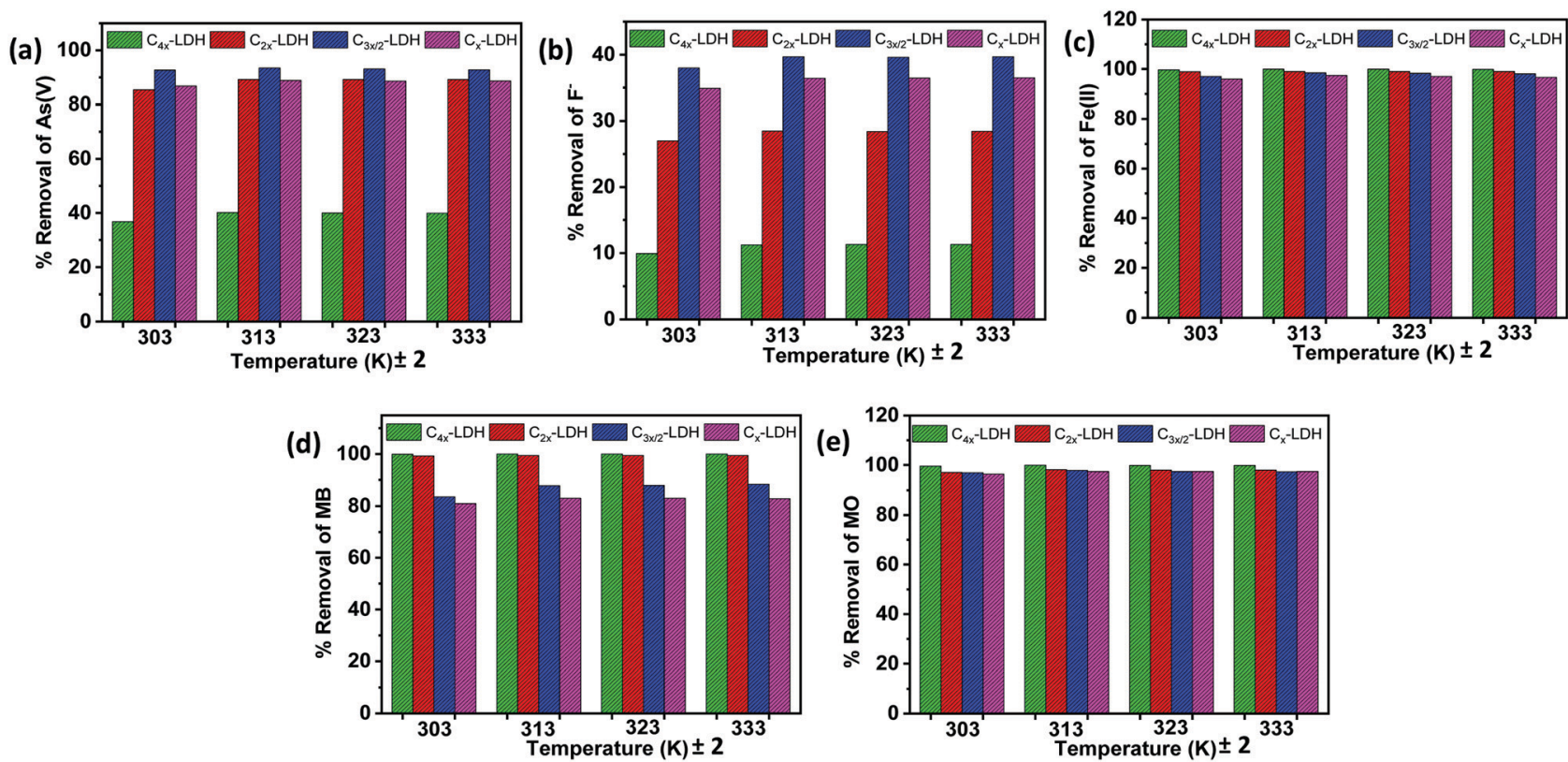

Fig. 10 The effect of temperature on the \% removal of the different $C$ - LDH composites $\left(C_{4 x}-L D H, C_{2 x}-L D H, C 3 x / 2-L D H\right.$ and $\left.C_{x}-L D H\right)$ for the adsorption of (a) As(v), (b) $F^{-}$, (c) Fe(II)/Fe(II), (d) MB and (e) MO. 

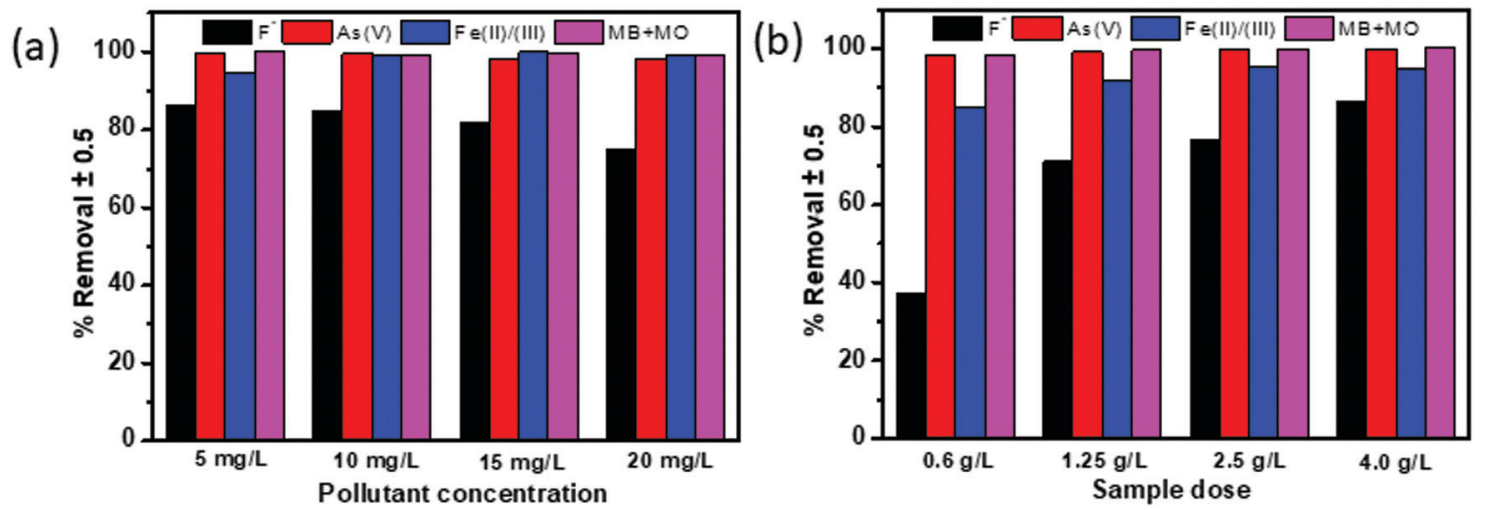

Fig. 11 (a) Percentage removal of $\mathrm{F}^{-}, \mathrm{As}(\mathrm{V}), \mathrm{Fe}(\mathrm{II}) / \mathrm{Fe}(\mathrm{III})$, and mixed dyes (MB and $\left.\mathrm{MO}\right)$ using composite $\mathrm{C}_{3 \times / 2}-\mathrm{LDH}$ by changing the pollutant concentration. (b) Percentage removal of $\mathrm{F}^{-}, \mathrm{As}(\mathrm{V}), \mathrm{Fe}(\mathrm{II}) / \mathrm{Fe}(\mathrm{III})$, and mixed dyes (MB and MO) using composite $\mathrm{C}_{3 \times / 2}-\mathrm{LDH}$ by changing the sample doses.

to synthesize the LDH sample in the absence of carbon. By changing the pollutant (adsorbate) concentrations, it was noticed that the \% removal for fluoride decreased from $86.5 \%$ to $75 \%$ with an increase in the adsorbate concentrations from 5 to $20 \mathrm{mg} \mathrm{L}^{-1}$. However, there were no significant changes in the \% removal of $\mathrm{As}(\mathrm{v})$ and the dyes $(\mathrm{MB}+\mathrm{MO})$ with an increase in the adsorbate concentration; it was $\sim 99 \%$ and $>99 \%$, respectively, for an adsorbate concentration in the range of $5-20 \mathrm{mg} \mathrm{L}^{-1}$. For the adsorption of $\mathrm{Fe}(\mathrm{II}) / \mathrm{Fe}(\mathrm{III})$, the \% removal increased from $95 \%$ to $99 \%$ by changing the adsorbate concentration from 5 to $10 \mathrm{mg} \mathrm{L}^{-1}$ followed by no significant change up to an adsorbate concentration of $20 \mathrm{mg} \mathrm{L}^{-1}$. The presence of co-existing ions of $\mathrm{As}(\mathrm{v})$ in the solution reduced the fluoride adsorption. It was reported that after adsorption of arsenate (As(v)) the zeta potential of the double layer on the surface is decreased significantly to negative values, and as a result fluoride adsorption on this negatively charged surface is inhibited. ${ }^{15,39}$ However, the removal of $\operatorname{As}(\mathrm{v})$ was not affected significantly in the presence of fluoride on the surface of the C-LDH composite. Generally, fluoride ions are adsorbed by a ligand exchange mechanism via exchange of surface $\mathrm{OH}^{-}$with $\mathrm{F}^{-}$. Therefore, fluoride adsorption should not change the charge and the potential of the surface of C-LDH during As(v) adsorption. $\mathrm{Fe}(\mathrm{II}) /$ $\mathrm{Fe}(\mathrm{III})$ is responsible for the enhanced adsorption capacity of $\mathrm{As}(\mathrm{V})$ via formation of arsenate- $\mathrm{Fe}(\mathrm{II}) / \mathrm{Fe}$ (III) complexes. ${ }^{40}$ In the presence of excess iron, this complex formation tendency is increased and arsenate is precipitated with excess iron. Consequently, removal of iron simultaneously facilitates arsenic removal from water.

Fig. 11(b) shows that, with an increase in the adsorbent (sample) dose from 0.625 to $3.75 \mathrm{~g} \mathrm{~L}^{-1}$, the adsorption efficiency (\%) slightly increased from $\sim 98 \%$ to $\sim 99.9 \%$ for the removal of $\mathrm{As}(\mathrm{v})$ and the dyes (MB + MO). However, there is a steady increase in the $\%$ removal of fluoride and $\mathrm{Fe}(\mathrm{II}) / \mathrm{Fe}(\mathrm{III})$ from $37 \%$ to $86 \%$ and $85 \%$ to $95 \%$, respectively, with an increase in the sample dose from 0.625 to $3.75 \mathrm{~g} \mathrm{~L}^{-1}$. The increase in the sample dose increases the number of active adsorption sites, which, in turn, enhances the adsorption capacity towards the removal of pollutants.

Effect of coexisting ions. Fig. 12 shows the effect of different co-existing ions like $\mathrm{Cl}^{-}, \mathrm{NO}_{3}{ }^{-}, \mathrm{SO}_{4}{ }^{2-}$ and $\mathrm{PO}_{4}{ }^{3-}$ on the removal of contaminants ( $\mathrm{As}(\mathrm{v}), \mathrm{F}^{-}, \mathrm{Fe}(\mathrm{II}) / \mathrm{Fe}(\mathrm{III}), \mathrm{MB}$ and MO). The initial concentration of each ion was kept at $5 \mathrm{mg} \mathrm{L}^{-1}$ at $\mathrm{pH} 7$ with a

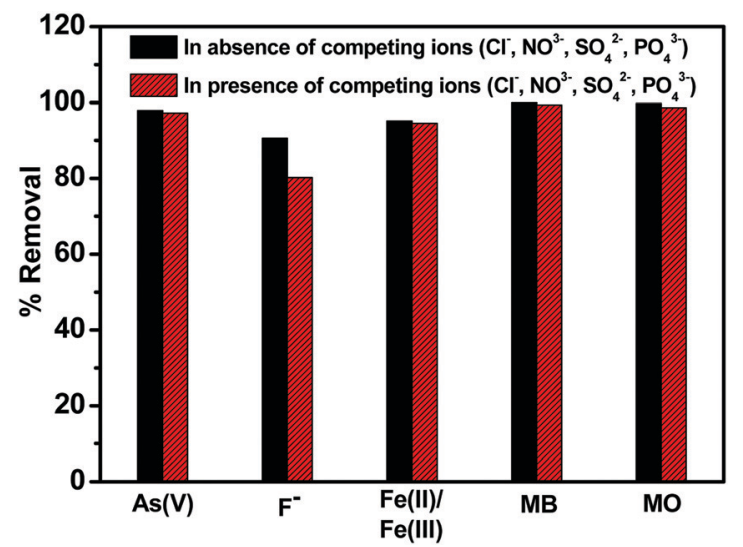

Fig. 12 Effect of coexisting ions on the adsorption of $\mathrm{As}(\mathrm{V}), \mathrm{F}^{-}, \mathrm{Fe}(\mathrm{II}) / \mathrm{Fe}(\mathrm{III})$, $\mathrm{MB}$ and $\mathrm{MO}$ by the $\mathrm{C}_{3 \times / 2}-\mathrm{LDH}$ nanocomposites.

contact time of $180 \mathrm{~min}$ at $30{ }^{\circ} \mathrm{C}$. It was found that the removal efficiency remains almost the same for the adsorption of $\mathrm{As}(\mathrm{V}), \mathrm{Fe}(\mathrm{II}) /$ $\mathrm{Fe}(\mathrm{III}), \mathrm{MB}$ and $\mathrm{MO}$ in the presence of competing ions. However, the percentage removal of $\mathrm{F}^{-}$was decreased in the presence of competing ions. The presence of $\mathrm{Cl}^{-}, \mathrm{NO}_{3}{ }^{-}, \mathrm{SO}_{4}{ }^{2-}$ and $\mathrm{PO}_{4}{ }^{3-}$ enhances the coulombic repulsion forces and they compete with $\mathrm{F}^{-}$ions for the active adsorption sites of the C-LDH nanocomposites. As a result, the removal efficiency for the adsorption of $\mathrm{F}^{-}$reduced in the presence of coexisting ions in water sources.

Study of regeneration and recyclability. The C-LDH composite sample was regenerated by washing with Millipore water and mild $\mathrm{NaOH}$ solution $(0.1 \mathrm{~N})$ multiple times to remove the adsorbed pollutants. A recyclability test was performed using the regenerated samples up to four consecutive cycles. It was found that the percentage removal remained almost the same up to the 4th cycle for adsorption of iron, MB and MO. However, the removal efficiency was found to be decreased from the 2nd cycle for the adsorption of arsenate and fluoride (Fig. 13).

\section{Mechanism of adsorption}

The synthesized composite material C-LDH showed significant adsorption capacity for removal of both inorganic (metal cations, anions and oxyanions) and organic (dyes) water pollutants due to 


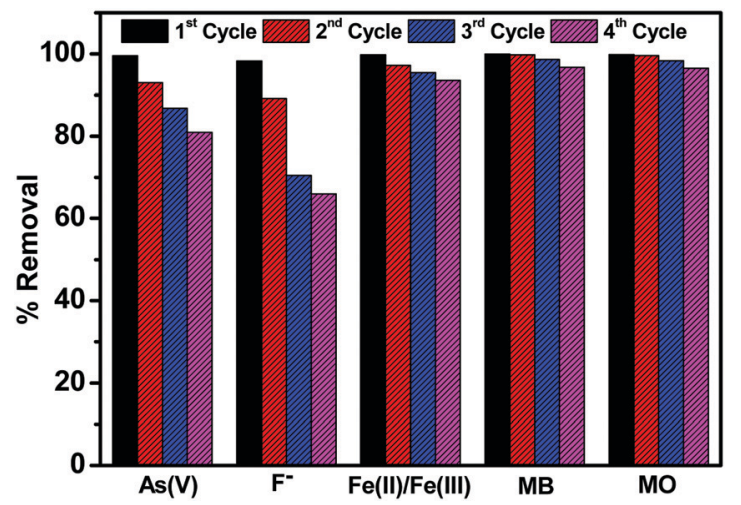

Fig. 13 Percentage removal for the adsorption of $\mathrm{As}(\mathrm{V}), \mathrm{F}^{-}, \mathrm{Fe}(\Perp) / \mathrm{Fe}\left({ }_{11}\right), \mathrm{MB}$ and $\mathrm{MO}$ on $\mathrm{C}_{3 \times / 2}-\mathrm{LDH}$ in four consecutive cycles.

the synergistic effect of the carbon and LDH content. The porous carbon in LDH structure helps improve the surface area, chemical stability and oxygen containing surface functional groups. As a consequence, the effective numbers of active adsorption sites are increased, rendering enhanced adsorption. Adsorption occurred via electrostatic interaction, ion exchange and complex formation mechanisms. Electrostatic attraction of arsenate ions with the C-LDH nanocomposite and complex formation with iron are the major removal mechanisms for arsenic. Fig. S14 in the ESI $\dagger$ shows an FTIR study (before and after adsorption of water pollutants) to understand the adsorption mechanism. The appearance of a peak at around $794 \mathrm{~cm}^{-1}$ signifies As-O bond formation after adsorption of As(v) onto $\mathrm{C}_{3 x / 2}-\mathrm{LDH}$. The reduction of the peak intensity at around $1379 \mathrm{~cm}^{-1}$ of the intercalated anions $\left(\mathrm{NO}_{3}{ }^{-}\right)$ signifies the partial replacement of interlayer anions of the LDH with arsenate and fluoride. On the other hand, it is observed that, after adsorption of contaminants onto the LDH structure, the intensity of the absorption band at around $654 \mathrm{~cm}^{-1}$ due to $\mathrm{Mg}-\mathrm{O}$ bonds is found to be diminished. It demonstrates that $\mathrm{Mg}^{2+}$ ions are partially exchanged by the pollutant ions during adsorption. ${ }^{24}$ Methyl orange is adsorbed on the C-LDH composites by electrostatic attraction between the dye molecules ( $\mathrm{MB}+\mathrm{MO})$ and the LDH. Additionally, the carbon in the LDH facilitates the formation of $\mathrm{H}$-bonding between anionic dye MO and carbon. Therefore, the cooperative contribution of electrostatic attraction and hydrogen bonding between the dye molecules and C-LDH composites is advantageous for the improvement of the adsorption capacity. ${ }^{41}$ Fig. 14 presents a tentative adsorption mechanism for removal of pollutants using the C-LDH composites. Four different C-LDH composite samples were synthesized by varying the concentration of carbon with respect to the LDH. From the removal study, it was found that sample $\mathrm{C}_{4 x} \mathrm{LDH}$ $(\mathrm{C}=0.06 \mathrm{~mol})$ showed higher adsorption of organic dyes and $\mathrm{Fe}(\mathrm{II}) / \mathrm{Fe}(\mathrm{III})$ compared to $\mathrm{As}(\mathrm{V})$ and $\mathrm{F}^{-}$removal. However, a decrease in the mols of carbon with respect to the LDH reduced the adsorption of organic dyes and increased the adsorption of $\operatorname{As}(\mathrm{v})$ and $\mathrm{F}^{-}$. For example, $\mathrm{C}_{x}-\mathrm{LDH}$ showed higher As(v) and $\mathrm{F}^{-}$ removal efficiency. From these findings, it can be mentioned that the porous structure of carbon is responsible for the removal of organic dyes and $\mathrm{Fe}(\mathrm{II}) / \mathrm{Fe}$ (III), whereas the interlayer

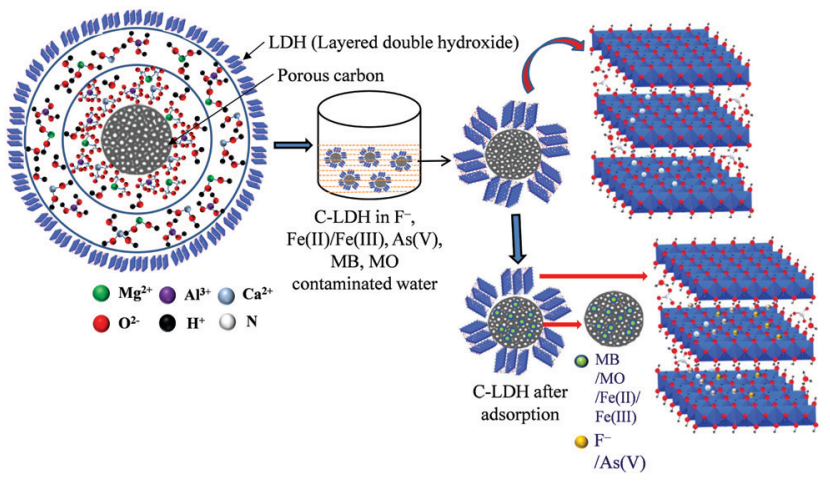

Fig. 14 Schematic representation of the removal of pollutants using the C-LDH composites.

space of the LDH structure adhered outside of the carbon sphere is utilized for removal of $\mathrm{As}(\mathrm{v})$ and $\mathrm{F}^{-}$. The simultaneous removal of pollutants can also be explained by the co-adsorption mechanism. ${ }^{42}$ The negatively charged arsenate and fluoride could improve the adsorption of positively charged dye MB through electrostatic interactions. On the other hand, the positively charged $\mathrm{Fe}(\mathrm{II}) / \mathrm{Fe}$ (III) facilitates the adsorption of negatively charged MO by electrostatic interactions. At the same time, N-containing groups of the adsorbed $\mathrm{MB}$ and $\mathrm{MO}$ could enhance the adsorption sites for arsenate, fluoride and iron. Therefore, the simultaneous removal mechanism could be attributed to the (i) presence of N-containing groups on the adsorbed MB and MO and (ii) electrostatic interaction through arsenate, fluoride and iron.

\section{Conclusions}

A C-LDH nanocomposite was prepared for simultaneous removal of $\mathrm{As}(\mathrm{V}), \mathrm{F}^{-}, \mathrm{Fe}(\mathrm{II}) / \mathrm{Fe}(\mathrm{III}), \mathrm{MB}$ and $\mathrm{MO}$ from water. The textural properties of the C-LDH composites indicate that the BET surface area $\left(S_{\mathrm{BET}}\right)$ values follow the order of $\mathrm{C}_{4 x}-\mathrm{LDH}$ $\left(758 \mathrm{~m}^{2} \mathrm{~g}^{-1}\right)>\mathrm{C}_{3 x / 2}-\mathrm{LDH}\left(558 \mathrm{~m}^{2} \mathrm{~g}^{-1}\right)>\mathrm{C}_{2 x}-\mathrm{LDH}\left(520 \mathrm{~m}^{2} \mathrm{~g}^{-1}\right)>$ $\mathrm{C}_{x}-\mathrm{LDH}\left(477 \mathrm{~m}^{2} \mathrm{~g}^{-1}\right)$, while the $S_{\text {mesopore }} / S_{\text {micropore values follow the }}$ trend of $\mathrm{C}_{3 x / 2}-\mathrm{LDH}>\mathrm{C}_{4 x}-\mathrm{LDH}>\mathrm{C}_{2 x}-\mathrm{LDH}>\mathrm{C}_{x}-\mathrm{LDH}$. The compositional variation of $\mathrm{C}: \mathrm{LDH}$ has an important role in changing the textural behaviours. The maximum removal \% of $\operatorname{As}(\mathrm{v})$ and $\mathrm{F}^{-}$for sample $\mathrm{C}_{3 x / 2} \mathrm{LDH}$ could be attributed to the high mesopore: micropore surface area ratio. For the removal of $\mathrm{Fe}(\mathrm{II}) /$ $\mathrm{Fe}(\mathrm{III}), \mathrm{MB}$ and MO, the trend of the adsorption \% for the samples is in the order of $\mathrm{C}_{4 x}-\mathrm{LDH}>\mathrm{C}_{2 x}-\mathrm{LDH}>\mathrm{C}_{3 x / 2}-\mathrm{LDH}>\mathrm{C}_{x}-\mathrm{LDH}$, which is in tune with the same order of the carbon content and surface area. The maximum adsorption capacity values for $\mathrm{As}(\mathrm{v})$ and $\mathrm{F}^{-}$removal are found to be 22.37 and $20.40 \mathrm{mg} \mathrm{g}^{-1}$, respectively, using $\mathrm{C}_{3 x / 2}-\mathrm{LDH}$, while sample $\mathrm{C}_{4 x}-\mathrm{LDH}$ shows the highest adsorption efficiency of $80.00,122.10$ and $328.95 \mathrm{mg} \mathrm{g}^{-1}$ for the adsorption of $\mathrm{Fe}(\mathrm{II}) / \mathrm{Fe}(\mathrm{III}), \mathrm{MB}$ and MO, respectively, at room temperature. The nature of the adsorbents and their relative concentration in the composite, total surface area and mesopore: micropore surface area ratio synergistically affect the removal of different inorganic and organic based contaminants from water. For simultaneous removal of $\mathrm{As}(\mathrm{V}), \mathrm{F}^{-}, \mathrm{Fe}(\mathrm{II}) / \mathrm{Fe}(\mathrm{III})$ and the dyes 
(MB and MO) with concentration $5 \mathrm{mg} \mathrm{L}^{-1}$ each from water, the composite material $\mathrm{C}_{3 x / 2}-\mathrm{LDH}$ having a $3.75 \mathrm{~g} \mathrm{~L}^{-1}$ dosage shows a percentage removal of $99.8 \%, 86.5 \%, 94.8 \%$ and $99.99 \%$, respectively, at pH $6.8 \pm 0.2$ and temperature $30{ }^{\circ} \mathrm{C}$. The present work is significant for the development of C-LDH nanocomposites for the removal of toxic water pollutants like As(v), $\mathrm{F}^{-}$, and $\mathrm{Fe}(\mathrm{II}) / \mathrm{Fe}$ (III) and different cationic and anionic dyes from waste water via an eco-friendly process.

\section{Conflicts of interest}

One patent application covering this work has been filed by CSIR-Central Glass \& Ceramic Research Institute (Indian patent application file no. 202011034408, dated 11.08.2020).

\section{Acknowledgements}

The authors are grateful to the Director of CSIR-CGCRI for his kind permission to pursue this work. The authors would like to acknowledge the financial support rendered by DST-SERB, Government of India, for funding the project (Sanction No. EEQ/2017/000004) under the project No. GAP 0622. An author (SK) is also thankful to CSIR (AcSIR) for granting a research fellowship (Grant No. 31/GATE/15(24)/2015-EMR-I).

\section{References}

1 X. Li, W.-c. Cao, Y.-g. Liu, G.-m. Zeng, W. Zeng, L. Qin and T.-t. Li, ACS Sustainable Chem. Eng., 2017, 5, 179-188.

2 J. Wei, M. F. Aly Aboud, I. Shakir, Z. Tong and Y. Xu, ACS Appl. Nano Mater., 2019, 3, 806-813.

3 G. Z. Kyzas and K. A. Matis, J. Mol. Liq., 2015, 203, 159-168.

4 A. Dạbrowski, Z. Hubicki, P. Podkościelny and E. Robens, Chemosphere, 2004, 56, 91-106.

5 G. L. Ghurye, D. A. Clifford and A. R. Tripp, J. Am. Water Works Assoc., 1999, 91, 85-96.

6 S. Rengaraj, K.-H. Yeon and S.-H. Moon, J. Hazard. Mater., 2001, 87, 273-287.

7 W. Ding, H. Tong, D. Zhao, H. Zheng, C. Liu, J. Li and F. Wu, Chem. Eng. J., 2020, 401, 126102.

8 M. Bayat, V. Javanbakht and J. Esmaili, Int. J. Biol. Macromol., 2018, 116, 607-619.

9 N. S. Graça, A. M. Ribeiro and A. E. Rodrigues, Chem. Eng. Sci., 2019, 197, 379-385.

10 S. Chakrabortty, M. Roy and P. Pal, Desalination, 2013, 313, 115-124.

11 M. Kumar, A. M. Isloor, T. S. Rao, A. F. Ismail, R. Farnood and P. Nambissan, Chem. Eng. J., 2020, 124367.

12 J. Shen and A. Schäfer, Chemosphere, 2014, 117, 679-691.

13 M. K. Uddin, Chem. Eng. J., 2017, 308, 438-462.

14 Z. Li, L. Wang, J. Meng, X. Liu, J. Xu, F. Wang and P. Brookes, J. Hazard. Mater., 2018, 344, 1-11.

15 C. Jing, J. Cui, Y. Huang and A. Li, ACS Appl. Mater. Interfaces, 2012, 4, 714-720.
16 M. Jourshabani, J. A. Dominic, G. Achari and Z. Shariatinia, Chem. Eng. Sci., 2019, 209, 115181.

17 M. M. Sabzehmeidani, S. Mahnaee, M. Ghaedi, H. Heidari and V. A. L. Roy, Mater. Adv., 2021, 2, 598-627, DOI: 10.1039/ D0MA00087F.

18 R. Saxena, M. Saxena and A. Lochab, ChemistrySelect, 2020, 5, 335-353.

19 G. Mishra, B. Dash and S. Pandey, Appl. Clay Sci., 2018, 153, 172-186.

20 I. Abe, S. Iwasaki, T. Tokimoto, N. Kawasaki, T. Nakamura and S. Tanada, J. Colloid Interface Sci., 2004, 275, 35-39.

21 S. M. Gidado and I. Akanyeti, Water, Air, Soil Pollut., 2020, 231, 1-18.

22 Y. Cao, G. Li and X. Li, Chem. Eng. J., 2016, 292, 207-223.

23 H.-P. Chao, Y.-C. Wang and H. N. Tran, Environ. Pollut., 2018, 243, 620-629.

24 S. Huang, S. Song, R. Zhang, T. Wen, X. Wang, S. Yu, W. Song, T. Hayat, A. Alsaedi and X. Wang, ACS Sustainable Chem. Eng., 2017, 5, 11268-11279.

25 X. Zhang, J. Wang, R. Li, Q. Dai, R. Gao, Q. Liu and M. Zhang, Ind. Eng. Chem. Res., 2013, 52, 10152-10159.

26 S. Kundu, I. H. Chowdhury and M. K. Naskar, J. Chem. Eng. Data, 2018, 63, 559-573.

27 S. Kundu and M. K. Naskar, J. Chem. Eng. Data, 2019, 64, 1594-1604.

28 L. K. G. Bhatta, S. Subramanyam, M. D. Chengala, U. M. Bhatta, P. Guha, R. P. H. Dinakar and K. Venkatesh, Energy Fuels, 2016, 30, 4244-4250.

29 G. Greczynski and L. Hultman, Prog. Mater. Sci., 2020, 107, 100591.

30 E. Diler, S. Rioual, B. Lescop, D. Thierry and B. Rouvellou, Corros. Sci., 2012, 65, 178-186.

31 E. Diler, B. Rouvellou, S. Rioual, B. Lescop, G. N. Vien and D. Thierry, Corros. Sci., 2014, 87, 111-117.

32 R. Steinberger, J. Walter, T. Greunz, J. Duchoslav, M. Arndt, S. Molodtsov, D. Meyer and D. Stifter, Corros. Sci., 2015, 99, 66-75.

33 T. Sumathi and G. Alagumuthu, Int. J. Chem. Eng., 2014, 2014, 430417, DOI: 10.1155/2014/430417.

34 J. S. Noh and J. A. Schwarz, J. Colloid Interface Sci., 1989, 130, 157-164.

35 T. Santhi and S. Manonmani, Chem. Eng. Res. Bull., 2009, 13, 1-5. 36 A. A. Moosa, A. M. Ridha and N. A. Kadhim, Am. J. Mater. Sci., 2016, 6, 135-146.

37 S. Rahdar, M. Taghavi, R. Khaksefidi and S. Ahmadi, Appl. Water Sci., 2019, 9, 87.

38 N. Gaur, A. Kukreja, M. Yadav and A. Tiwari, Appl. Water Sci., 2018, 8, 98.

39 M. Pena, X. Meng, G. P. Korfiatis and C. Jing, Environ. Sci. Technol., 2006, 40, 1257-1262.

40 L. Twidwell, R. Robins and J. Hohn, Arsenic Metall., 2005, 3-24. 41 M. Zhang, Q. Yao, C. Lu, Z. Li and W. Wang, ACS Appl. Mater. Interfaces, 2014, 6, 20225-20233.

42 S. Chen, Y. Huang, X. Han, Z. Wu, C. Lai, J. Wang, Q. Deng, Z. Zeng and S. Deng, Chem. Eng. J., 2018, 352, 306-315. 